Article

\title{
Towards the Inhibition of Protein-Protein Interactions (PPIs) in STAT3: Insights into a New Class of Benzothiadiazole Derivatives
}

\author{
Matteo Mori ${ }^{1}{ }^{\circledR}$, Ettore Gilardoni ${ }^{1}{ }^{(}$, Luca Regazzoni $^{1, *}{ }^{1}$, Alessandro Pedretti ${ }^{1}{ }^{(}$, \\ Diego Colombo $^{2} \mathbb{D}$, Gary Parkinson ${ }^{3} \mathbb{D}$, Akira Asai ${ }^{4}$, Fiorella Meneghetti ${ }^{1} \mathbb{D}$, Stefania Villa $1, * \mathbb{D}$ \\ and Arianna Gelain ${ }^{1}$ (D) \\ 1 Department of Pharmaceutical Sciences, University of Milan, via L. Mangiagalli 25, 20133 Milano, Italy; \\ matteo.mori@unimi.it (M.M.); ettore.gilardoni@unimi.it (E.G.); alessandro.pedretti@unimi.it (A.P.); \\ fiorella.meneghetti@unimi.it (F.M.); arianna.gelain@unimi.it (A.G.) \\ 2 Department of Medical Biotechnology and Translational Medicine, University of Milan, via C. Saldini 50, \\ 20133 Milano, Italy; diego.colombo@unimi.it \\ 3 Department of Pharmaceutical and Biological Chemistry-UCL School of Pharmacy, University College \\ London, 29/39 Brunswick Square, London WC1N 1AX, UK; gary.parkinson@ucl.ac.uk \\ 4 Center for Drug Discovery—Graduate School of Pharmaceutical Sciences, University of Shizuoka, 52-1 Yada, \\ Suruga-ku, Shizuoka 422-8526, Japan; aasai@u-shizuoka-ken.ac.jp \\ * Correspondence: luca.regazzoni@unimi.it (L.R.); stefania.villa@unimi.it (S.V.); Tel.: +39-02-50319368 (S.V.)
}

Received: 24 June 2020; Accepted: 29 July 2020; Published: 31 July 2020

\begin{abstract}
Signal transducer and activator of transcription 3 (STAT3) is a validated anticancer target due to the relationship between its constitutive activation and malignant tumors. Through a virtual screening approach on the STAT3-SH2 domain, 5,6-dimethyl-1H,3H-2,1,3-benzothiadiazole-2,2dioxide (1) was identified as a potential STAT3 inhibitor. Some benzothiadiazole derivatives were synthesized by employing a versatile methodology, and they were tested by an AlphaScreen-based assay. Among them, benzosulfamide 1 showed a significant activity with an $\mathrm{IC}_{50}=15.8 \pm 0.6 \mu \mathrm{M}$ as a direct STAT3 inhibitor. Notably, we discovered that compound 1 was also able to interact with cysteine residues located around the $\mathrm{SH} 2$ domain. By applying mass spectrometry, liquid chromatography, NMR, and UV spectroscopy, an in-depth investigation was carried out, shedding light on its intriguing and unexpected mechanism of interaction.
\end{abstract}

Keywords: benzosulfamides; structure-based virtual screening; STAT3-SH2 domain; cysteine binder; diversity-oriented synthesis

\section{Introduction}

Since the discovery of the relationship between the constitutive activation of signal transducer and activator of transcription 3 (STAT3) and malignant tumors, the validation of STAT3 as a target has been supported by a large number of studies. Various compounds with STAT3 inhibitory activity have been reported in recent years, including potent inhibitors such as Stattic, S3I-201, and erasin [1-4]. Nevertheless, these molecules are mostly at the experimental stage, and only few are in clinical trials [5]. Hence, the challenge is the discovery of new selective candidates with high potency and in vivo activity. Since a direct inhibitory approach should be preferred, we addressed our efforts to the disruption of STAT3 homodimerization, an essential step in its activation, targeting the protein-protein interactions (PPIs). The large surface area of STAT3 and the chemistry of these interactions [6], which are very different from those of better-known targets such as enzymes and G-protein-coupled receptors, could represent significant hurdles, although a number of successful examples have demonstrated that it is 
possible to overcome them and develop PPI modulators [7]. Since the binding of a ligand to a hot spot should compete with the original protein partner of the PPI, thus resulting in disruption of its function, the aim of our ongoing studies [8-13] is the identification of small molecules that are able to bind the Src homology 2 (SH2) domain of STAT3, preventing STAT3 dimerization and thus its activation. With this purpose, in the present work, some compound libraries were analyzed by means of a structure-based virtual screening performed on the STAT3-SH2 domain (see the Molecular Modeling section). Among the candidates that reached the best scores in the docking study, we decided to focus our attention on the compounds that bear a sulfone moiety, which is a common feature in some STAT3-SH2 inhibitors reported in the literature [1,2].

In order to support the docking results, the selected compounds were either purchased or synthesized, and their ability to interact with the STAT3-SH2 domain was evaluated via an in vitro binding test (AlphaScreen-based assay) at $30 \mu \mathrm{M}$; the most interesting results are reported in Table 1 . Hence, we identified the benzothiadiazole derivative $\mathbf{1}$ as a promising hit compound that carries a chemically accessible moiety for further development.

Table 1. Inhibitory activities of compounds 1 and I-III.

Compound

The significant inhibitory activity exhibited by 5,6-dimethyl-1H,3H-2,1,3-benzothiadiazole-2,2dioxide (1) prompted us to fully characterize it by means of an X-ray analysis. Moreover, we designed and synthesized a small library of derivatives bearing different substituents on the aromatic and thiadiazole rings (1a-i, 2a, b, 3, 4). Furthermore, imidazol-2-one (5) and thiophene dioxide (6) moieties (replacing the thiadiazole ring (Figure 1)) were assessed to develop a preliminary structure-activity relationship (SAR) on this class of compounds.

For the synthesis of $\mathbf{1 a}-\mathbf{i}$, we employed an adaptable methodology [14] that also considered a diversity-oriented approach using suitable monoprotected intermediates. For derivatives $\mathbf{2} \mathbf{a}, \mathbf{b}, \mathbf{3}$, and $\mathbf{4}$, our synthetic strategy was planned to allow for the introduction of different substituents on compound (1) by the direct alkylation of the sulfamide moiety.

Herein, we describe the in silico-based rational design, synthesis, characterization, and interaction with the STAT3-SH2 domain of new inhibitors bearing the benzosulfamide scaffold. Furthermore, since several STAT3 inhibitors have been reported as irreversible cysteine binders (e.g., Stattic and S3I-201) [15-18], we decided to evaluate the activity of compound 1 versus the cysteine residues located around the STAT3-SH2 domain (Cys468, Cys542, Cys550, Cys687, and Cys712) and to shed light on its mechanism of interaction by MS, UV, LC, and NMR studies. 


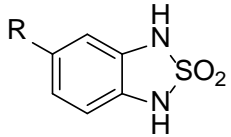

1a $\mathrm{R}^{=} \mathrm{H}$

1b $\mathrm{R}=\mathrm{CH}_{3}$

1c $\mathrm{R}=\mathrm{CF}_{3}$

1d $\mathrm{R}=\mathrm{NO}_{2}$

1e $\mathrm{R}=\mathrm{Cl}$

1f $\mathrm{R}=\mathrm{NHCOCH}_{3}$

1g R $=\left(\mathrm{CH}_{2}\right)_{2} \mathrm{CONH}_{(}\left(\mathrm{CH}_{2}\right)_{2} \mathrm{CH}_{(}\left(\mathrm{CH}_{3}\right)_{2}$

1h $\mathrm{R}=\left(\mathrm{CH}_{2}\right)_{2} \mathrm{CONHPh}$

1i $\mathrm{R}=\mathrm{Ph}$

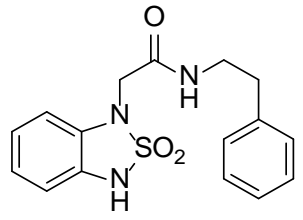

4

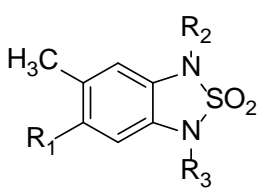

2a $\mathrm{R}_{1}={ }_{B} r ; R_{2}, R_{3}=H$

2b $\mathrm{R}_{1}=\mathrm{H} ; \mathrm{R}_{2} \cdot \mathrm{R}_{3}=\mathrm{CH}_{3}$

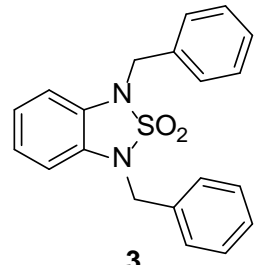

3<smiles>O=c1[nH]c2ccccc2[nH]1</smiles>

5

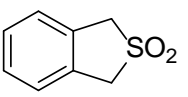

6

Figure 1. Library of 5,6-dimethyl- $1 H, 3 H-2,1,3$-benzothiadiazole-2,2-dioxide (1) derivatives.

\section{Results and Discussion}

\subsection{Molecular Modeling-Design and Chemical Space Exploration}

In order to identify new direct STAT3 inhibitors, molecular modeling studies were carried out. In particular, a virtual screening approach was applied to compound databases with the aim to select a series of candidates endowed with the best binding scores. Therefore, we performed a structure-based virtual screening, choosing STAT3 in complex with a DNA fragment (Protein Data Bank (PDB) ID 1BG1) [19] as a model and employing a set of databases of small molecules, namely: AKos (544391 molecules), ChemPDB (4009), ChemBank (2344), Kyoto Encyclopedia of Genes and Genomes-Compound (KEGG, 10005), National Cancer Institute Anti-HIV( NCI's Anti-HIV, 42689), and National Cancer Institute (NCI, 15237).

Each molecule was ranked on the basis of the docking score (interaction energy of AutoDock 4) [20] of the best solution. In this way, a list of compounds was obtained in which the first and the last molecules were, respectively, the best and the worst interacting ones. This list made the next step of the analysis easier because only the first 500 compounds for each database were further considered. Hence, the best molecules were classified on the basis of the most recurrent moieties: (e.g., sulfonic acids, sulfonamides, sulfamates, phosphates, and diketones; Tables S1-S5, Supplementary Materials). This kind of clustering was performed by encoding the moieties into SMARTS patterns and performing queries on the databases of the top-ranked poses, as implemented in the VEGA $\mathrm{ZZ}$ program. These results were very interesting because the functional groups included negatively charged atoms, such as oxygens, which can mimic the phosphate moiety of Tyr705 (pTyr-705), upon interaction with positively charged amino acids. A further selection was performed based on the commercial availability, synthetic accessibility, and size of the molecules. In particular, small molecules were privileged because, in the future, they may be included in peptidic derivatives to improve their selectivity. Therefore, drawing inspiration from compounds reported in the literature [1,2], we decided to focus on the cyclic sulfonamide moiety, ultimately selecting compounds with a molecular weight lower than $300 \mathrm{Da}$. The biological activity of several candidates belonging to the NCI collection was evaluated by an AlphaScreen-based assay, and among the most interesting hits, compound $\mathbf{1}$ emerged as a promising lead for further development (Table 1). The analysis of its docking pose (see Figure S1) revealed that compound 1 may interact with the SH2 domain through the insertion of its sulfonamide moiety into the polar pocket lined by Arg-609 and Lys-591; moreover, it showed that the compound 
occupies most of the pocket volume normally filled by pTyr-705 in the dimerized STAT3. Starting from this qualitative analysis of the binding mode, it seems reasonable to hypothesize that this molecule could act as a reversible inhibitor of STAT3 dimerization.

\subsection{Chemistry}

Compounds $\mathbf{1}$ and $\mathbf{1 a}-\mathbf{d}$ were synthesized from the corresponding commercially available ortho-diamines through a direct cyclization in the presence of sulfamide and diglyme (Scheme 1) [21].

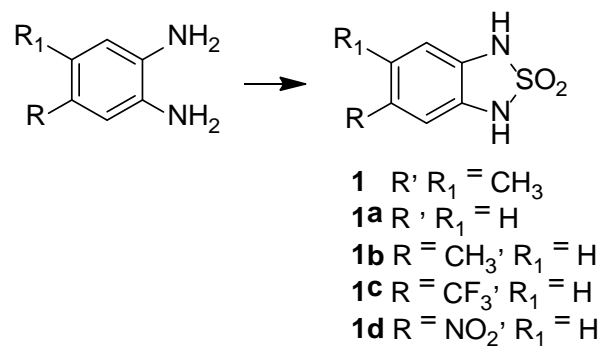

Scheme 1. Reagents and conditions: $\mathrm{NH}_{2} \mathrm{SO}_{2} \mathrm{NH}_{2}$, diglyme, reflux, $40 \mathrm{~min}$ (10 min for compound 1).

Compound 1 showed acidic properties ( $\mathrm{pKa}=6.88 \pm 0.03$ ) [22] and was fully characterized by X-ray diffraction. Its crystal structure is shown in Figure 2 as an ORTEP [23] drawing (Figure 2).

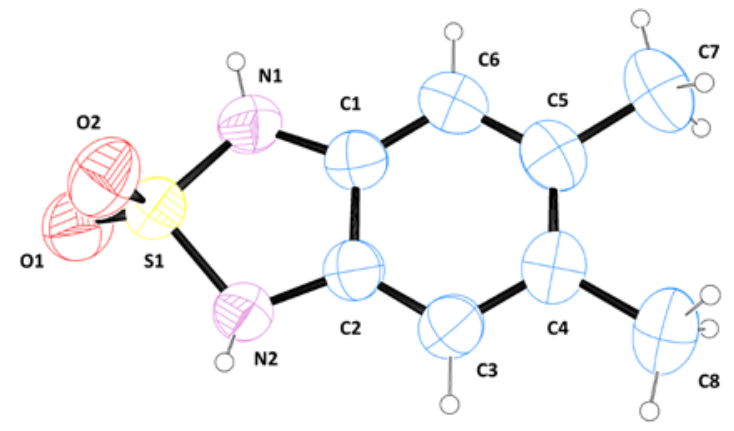

Figure 2. ORTEP [23] view of compound 1 and the relative arbitrary atom-numbering scheme (thermal ellipsoids at $50 \%$ probability).

Products 1e and 2a were obtained starting from 2,4-dichloro-1-nitrobenzene and 1,5-dibromo2-methyl-4-nitrobenzene, respectively. They were reacted with 2,4-dimethoxybenzylamine $\left(\mathrm{DMB}-\mathrm{NH}_{2}\right)$ or 4-methoxybenzylamine (PMB- $\mathrm{NH}_{2}$ ) to give intermediates 7 and $\mathbf{8}$, respectively, which were converted to the corresponding amines $\mathbf{9}$ and $\mathbf{1 0}$ through reduction with zinc and ammonium chloride. By treatment with sulfamide, $\mathbf{9}$ and $\mathbf{1 0}$ underwent a cyclization reaction, thus affording intermediates 11 and 12. These benzothiadiazole derivatives were deprotected with trifluoroacetic acid (TFA) to yield the final products $1 \mathbf{e}$ and $\mathbf{2 a}$, respectively (Scheme 2).

Product $\mathbf{1 f}$ was obtained starting from compound 1d, which was protected by treatment with $\mathrm{PMB}-\mathrm{Br}$ and potassium carbonate to afford intermediate 13; its reduction with zinc and ammonium chloride gave the amine 14. The latter, through a reaction with acetic anhydride, afforded intermediate 15, which was deprotected with TFA to give product 1f (Scheme 3).

Intermediate 19, the starting reagent for the synthesis of products $1 \mathrm{~g}-\mathbf{i}$, was obtained as reported in Scheme 4: the reaction of 2,5-dibromo-nitrobenzene with $\mathrm{PMB}-\mathrm{NH}_{2}$ led to intermediate 16, which was reduced to give the amine $\mathbf{1 7}$ in the presence of zinc and ammonium chloride. By treatment with sulfamide, 17 was cyclized, thus affording the benzothiadiazole derivative 18, which was subsequently protected with PMB-Br to yield compound 19 (Scheme 4). 


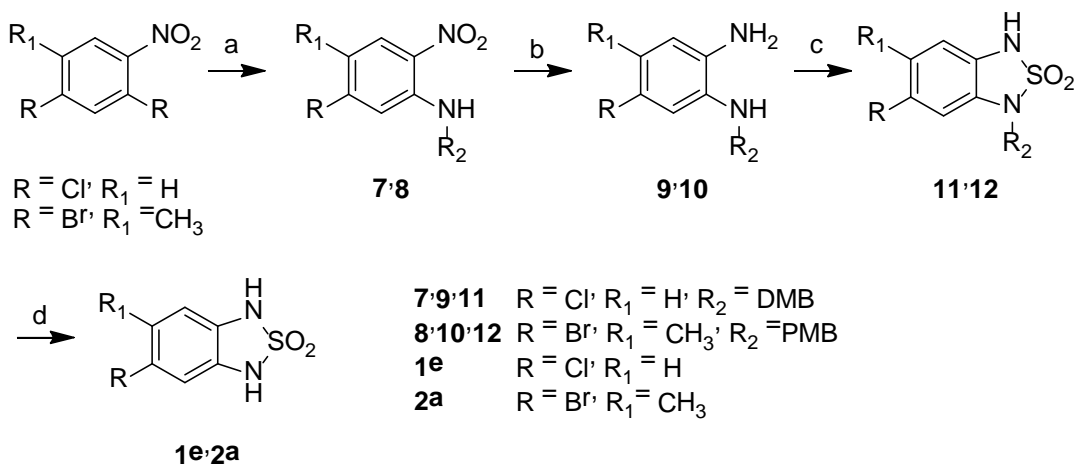

Scheme 2. Reagents and conditions: (a) 2,4-dimethoxybenzylamine $\left(\mathrm{DMB}^{\left.-\mathrm{NH}_{2}\right)}\right.$ (for 7) or 4-methoxybenzylamine (PMB- $\mathrm{NH}_{2}$ ) (for 8), isopropanol, reflux, $12 \mathrm{~h}$; (b) $\mathrm{Zn}, \mathrm{NH}_{4} \mathrm{Cl}, \mathrm{MeOH} / \mathrm{H}_{2} \mathrm{O}(9: 1$ ), reflux, $3 \mathrm{~h}$; (c) $\mathrm{NH}_{2} \mathrm{SO}_{2} \mathrm{NH}_{2}$, dry diglyme, $160^{\circ} \mathrm{C}, 1.5 \mathrm{~h}$; and (d) trifluoroacetic acid (TFA), DCM, $50{ }^{\circ} \mathrm{C}$, $1.5 \mathrm{~h}$.
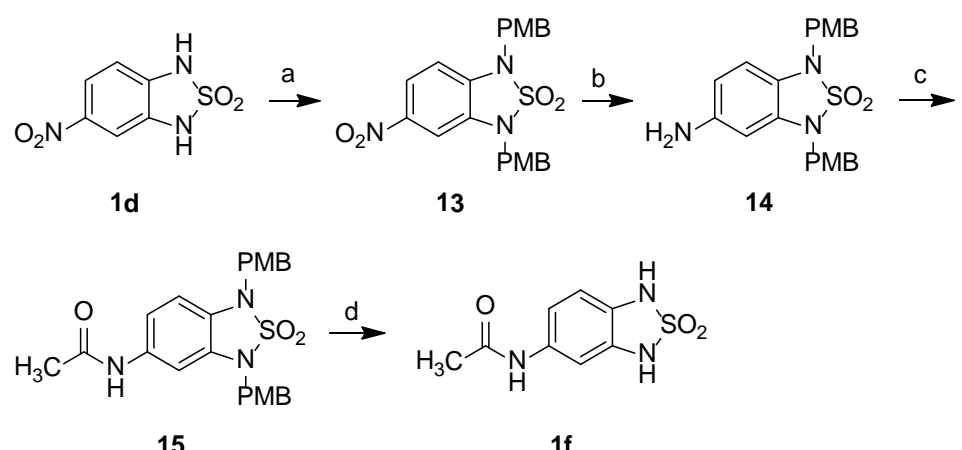

Scheme 3. Reagents and conditions: (a) PMB-Br, dry $\mathrm{K}_{2} \mathrm{CO}_{3}$, dry DMF, $80{ }^{\circ} \mathrm{C}, 2 \mathrm{~h}$; (b) $\mathrm{Zn}, \mathrm{NH}_{4} \mathrm{Cl}$, $\mathrm{MeOH} / \mathrm{H}_{2} \mathrm{O}$ (9:1), reflux, 3 h; (c) $\left(\mathrm{CH}_{3} \mathrm{COO}\right)_{2} \mathrm{O},\left(\mathrm{CH}_{3}\right)_{2} \mathrm{CO}$, r.t., 3 h; and (d) TFA, DCM, r.t., 8 h.

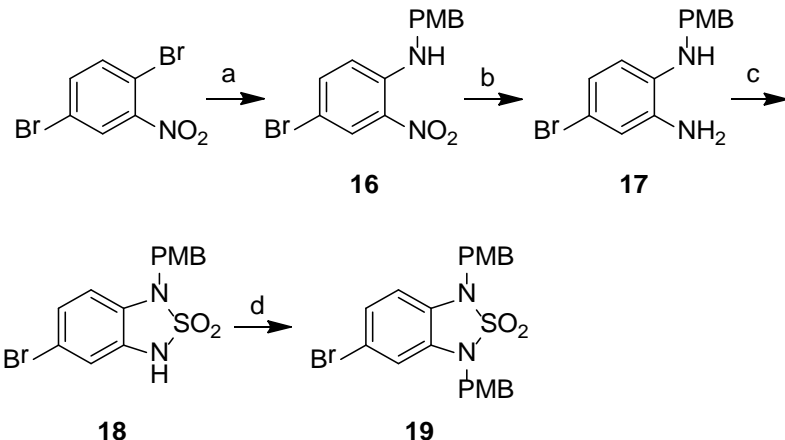

Scheme 4. Reagents and conditions: (a) $\mathrm{PMB}^{-\mathrm{NH}_{2}}$, reflux, $8 \mathrm{~h}$; (b) $\mathrm{Zn}, \mathrm{NH}_{4} \mathrm{Cl}, \mathrm{MeOH} / \mathrm{H}_{2} \mathrm{O}$ (9:1), reflux, $4 \mathrm{~h}$; (c) $\mathrm{NH}_{2} \mathrm{SO}_{2} \mathrm{NH}_{2}$, dry diglyme, $160{ }^{\circ} \mathrm{C}, 3 \mathrm{~h}$; and (d) PMB-Br, dry $\mathrm{K}_{2} \mathrm{CO}_{3}$, dry DMF, $80{ }^{\circ} \mathrm{C}, 2 \mathrm{~h}$.

Afterwards, intermediate 19 was reacted with ethyl acrylate in the presence of tri-o-tolylphosphine and tris(dibenzylideneacetone)dipalladium(0) to afford the ester 20 . The latter was hydrolyzed under basic conditions to the corresponding acid 21, which was converted to the amides 22 and 23 using isopentylamine, HATU, and N,N-diisopropylethylamine or aniline, TBTU, and N-methylmorpholine, respectively. By catalytic hydrogenation with $10 \% \mathrm{Pd} / \mathrm{C}$, they were reduced and deprotected to give products $\mathbf{1 g}$ and $\mathbf{1 h}$ (Scheme 5). 


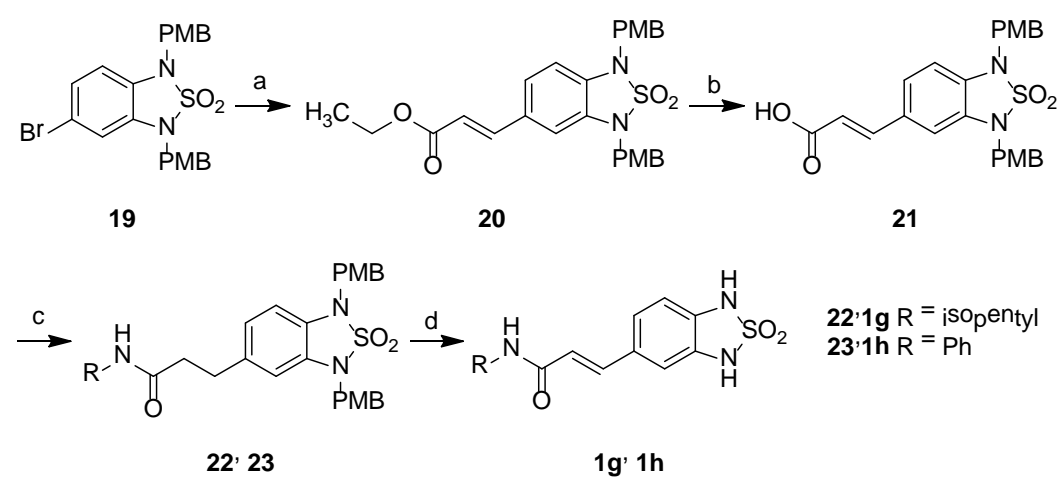

Scheme 5. Reagents and conditions: (a) ethyl acrylate, $\mathrm{P}(\mathrm{o} \text {-tol })_{3}, \mathrm{Pd}_{2}(\mathrm{dba})_{3}$, TEA, dry $\mathrm{DMF}, 80{ }^{\circ} \mathrm{C}, 20 \mathrm{~h}$; (b) $3 \mathrm{M} \mathrm{NaOH}, \mathrm{MeOH}, 80^{\circ} \mathrm{C}, 3 \mathrm{~h}$; (c) isopentylamine, HATU, DIPEA, DCM, r.t., $20 \mathrm{~h}$ (for 22) or aniline,

TBTU, $N$-methylmorpholine, DCM, r.t., 24 h (for 23); and (d) $\mathrm{H}_{2}$ (3 atm), 10\% Pd/C, EtOH, r.t., 48 h.

Moreover, compound 19 was arylated through a Suzuki reaction with phenylboronic acid in the presence of tetrakis(triphenylphosphine)palladium(0) to give intermediate 24, which was then deprotected by treatment with TFA, thus affording product 1i (Scheme 6).

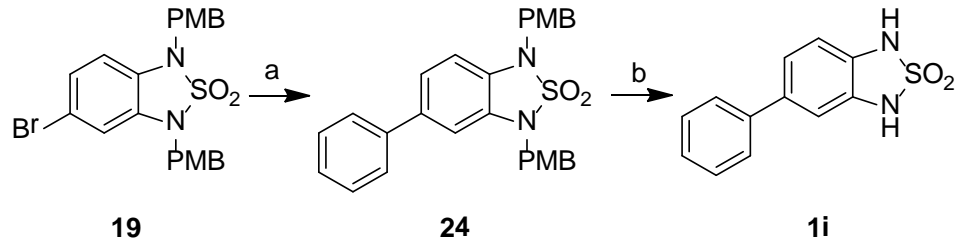

Scheme 6. Reagents and conditions: (a) $\mathrm{PhB}(\mathrm{OH})_{2}, \mathrm{Pd}\left(\mathrm{PPh}_{3}\right)_{4}, \mathrm{Na}_{2} \mathrm{CO}_{3}, 1$,4-dioxane, reflux, $20 \mathrm{~h}$; and (b) TFA, DCM, r.t., 3 h.

Products $\mathbf{2 b}$ and $\mathbf{3}$ were obtained from compounds $\mathbf{1 b}$ and $\mathbf{1 a}$, respectively, through alkylation with iodomethane or benzyl bromide in the presence of potassium carbonate (Scheme 7).

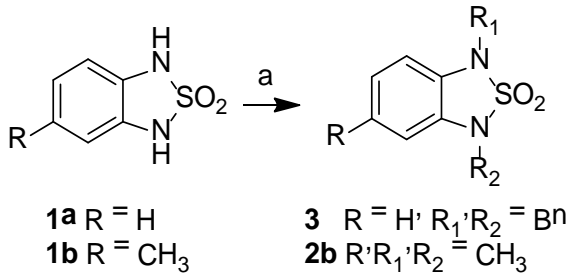

Scheme 7. Reagents and conditions: $\mathrm{CH}_{3} \mathrm{I}$ (for $\mathbf{2 b}$ ) or $\mathrm{BnBr}$ (for 3), dry $\mathrm{K}_{2} \mathrm{CO}_{3}$, and dry $\mathrm{DMF}, 80^{\circ} \mathrm{C}, 2 \mathrm{~h}$.

Product 4 was prepared through a reaction of 1-chloro-2-nitrobenzene with $\mathrm{DMB}-\mathrm{NH}_{2}$ to obtain intermediate 25, which was reduced using zinc and ammonium chloride to give the amine 26 . Its cyclization with sulfamide led to intermediate 27 , which was firstly esterified with ethyl bromoacetate to give intermediate $\mathbf{2 8}$ and then hydrolyzed under basic conditions to the corresponding acid 29. This intermediate was condensed with 2-phenylethylamine to afford the amide 30, which was deprotected with TFA, thus leading to the product 4 (Scheme 8). 


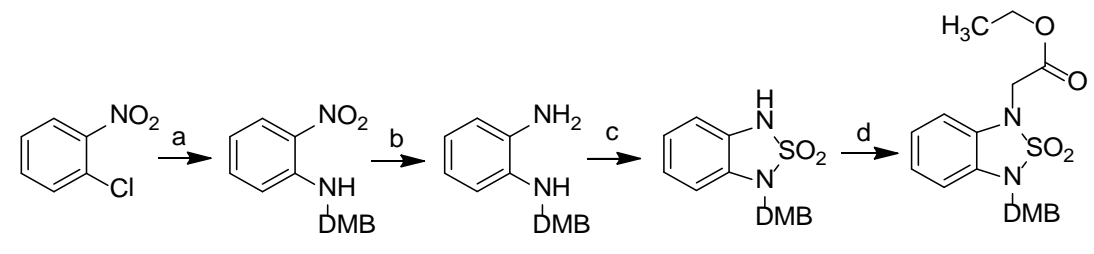

25

26

27

28

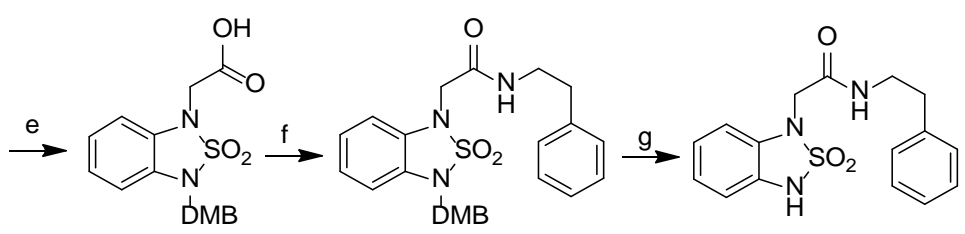

29

30

4

Scheme 8. Reagents and conditions: (a) DMB- $\mathrm{NH}_{2}, \mathrm{EtOH}$, reflux, $12 \mathrm{~h}$; (b) $\mathrm{Zn}, \mathrm{NH}_{4} \mathrm{Cl}, \mathrm{MeOH} / \mathrm{H}_{2} \mathrm{O}$ (9:1), reflux; (c) $\mathrm{NH}_{2} \mathrm{SO}_{2} \mathrm{NH}_{2}$, dry diglyme, $160^{\circ} \mathrm{C}$, $1.5 \mathrm{~h}$; (d) $\mathrm{BrCH}_{2} \mathrm{COOCH}_{2} \mathrm{CH}_{3}$, dry $\mathrm{K}_{2} \mathrm{CO}_{3}$, dry DMF, $80{ }^{\circ} \mathrm{C}, 2 \mathrm{~h}$; (e) $\mathrm{K}_{2} \mathrm{CO}_{3}, \mathrm{MeOH}, 50{ }^{\circ} \mathrm{C}, 2 \mathrm{~h}$; (f) $\mathrm{Ph}\left(\mathrm{CH}_{2}\right)_{2} \mathrm{NH}_{2}$, HATU, DIPEA, DCM, r.t., 12 h; and (g) TFA, DCM, $45^{\circ} \mathrm{C}, 45 \mathrm{~min}$.

Product 5 was achieved through the cyclization of benzene-1,2-diamine in the presence of carbonyldiimidazole (CDI) (Scheme 9).

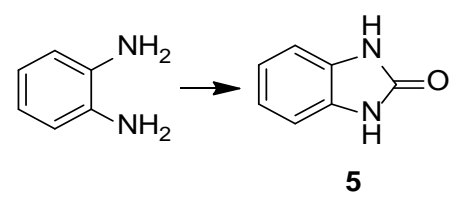

Scheme 9. Reagents and conditions: CDI, dry THF, reflux, $12 \mathrm{~h}$.

Finally, compound 6 was purchased from commercial sources.

\subsection{Biological Evaluation}

AlphaScreen is an in vitro competitive binding test used to identify compounds that are able to inhibit the binding of proteins containing an $\mathrm{SH} 2$ domain to their corresponding phosphopeptides (5-carboxyfluorescein (FITC)-GpYLPQTV for STAT3 and FITC-GpYDKPHVL for STAT1) (Table 2). Compounds characterized by an interesting STAT3 affinity were further investigated for their selectivity versus STAT1, which shows a high degree of sequence similarity to STAT3 but an opposite physiological role [24,25], and Grb2, as a model for other SH2 domain-containing proteins.

The significant activity of compound 1 , revealed at $30 \mu \mathrm{M}$ (Table 2), prompted us to test this compound at different concentrations. Therefore, we calculated its $\mathrm{IC}_{50}$ values against STAT3 and STAT1 to be $15.8 \pm 0.6$ and $>50 \mu \mathrm{M}$, respectively, while the inhibition versus Grb2 was $23 \%$ (at a $30 \mu \mathrm{M}$ concentration).

To identify a trend in terms of structure-activity relationship, we firstly explored the role of the substituents on the benzene ring (1a-i). In this respect, we found that lipophilicity does not play an important role in modulating STAT3 inhibitory activity. Bulky lipophilic substituents at position 5 (derivatives $\mathbf{1 g}$ and $\mathbf{1 h}$ ) induced a significant drop in the inhibition properties (Table 2). Among these derivatives, only $\mathbf{1 d}$, bearing a $\mathrm{NO}_{2}$ group at position 5 , exhibited a noticeable activity against STAT3. For this compound, we calculated the $\mathrm{IC}_{50}$ values against STAT3 and STAT1, which were $25.1 \pm 2.6 \mu \mathrm{M}$ and $15.9 \pm 2.0 \mu \mathrm{M}$, respectively, revealing no selectivity for STAT3 inhibition. Then, we introduced different groups on the nitrogen atoms of the thiadiazole ring $(\mathbf{2} \mathbf{a}, \mathbf{b}, \mathbf{3}$, and $\mathbf{4})$, in order to explore asymmetrical substitutions: The presence of the $\mathrm{N}$-substituent did not improve activity. 
The enhanced bulkiness and hydrophobicity of these substituents compared to compound $\mathbf{1}$ did not lead to a better interaction.

Table 2. Inhibitory activities of compounds 1, 1a-i, 2a-b, and 3-6. STAT3: signal transducer and activator of transcription 3 .

\begin{tabular}{|c|c|c|}
\hline & 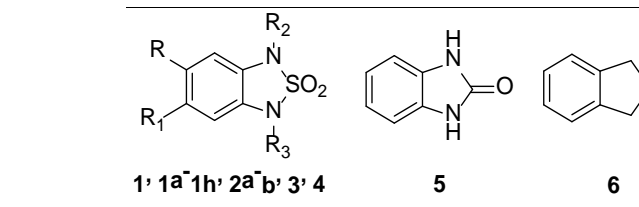 & \\
\hline Compound & Substituents & STAT3 \% Inhibition $(30 \mu \mathrm{M})$ \\
\hline 1 & $\mathrm{R}, \mathrm{R}_{1}=\mathrm{CH}_{3} ; \mathrm{R}_{2}, \mathrm{R}_{3}=\mathrm{H}$ & $96.5 \pm 1.1^{[\mathrm{a}]}$ \\
\hline 1a & $\mathrm{R}, \mathrm{R}_{1}, \mathrm{R}_{2}, \mathrm{R}_{3}=\mathrm{H}$ & $16.4 \pm 0.8^{[b]}$ \\
\hline $1 b$ & $\mathrm{R}=\mathrm{H} ; \mathrm{R}_{1}=\mathrm{CH}_{3} ; \mathrm{R}_{2}, \mathrm{R}_{3}=\mathrm{H}$ & $14.5 \pm 0.6^{[\mathrm{b}]}$ \\
\hline 1c & $\mathrm{R}=\mathrm{H} ; \mathrm{R}_{1}=\mathrm{CF}_{3} ; \mathrm{R}_{2}, \mathrm{R}_{3}=\mathrm{H}$ & $8.2 \pm 1.6^{[\mathrm{b}]}$ \\
\hline 1d & $\mathrm{R}=\mathrm{H} ; \mathrm{R}_{1}=\mathrm{NO}_{2} ; \mathrm{R}_{2}, \mathrm{R}_{3}=\mathrm{H}$ & $56.9 \pm 3.6^{[c]}$ \\
\hline $1 e$ & $\mathrm{R}=\mathrm{H} ; \mathrm{R}_{1}=\mathrm{Cl} ; \mathrm{R}_{2}, \mathrm{R}_{3}=\mathrm{H}$ & $28.2 \pm 1.4^{[b]}$ \\
\hline $1 f$ & $\mathrm{R}=\mathrm{H} ; \mathrm{R}_{1}=\mathrm{NHCOCH}_{3} ; \mathrm{R}_{2}, \mathrm{R}_{3}=\mathrm{H}$ & $18.9 \pm 2.3^{[b]}$ \\
\hline $1 \mathrm{~g}$ & $\mathrm{R}=\mathrm{H} ; \mathrm{R}_{1}=\left(\mathrm{CH}_{2}\right)_{2} \mathrm{CONH}\left(\mathrm{CH}_{2}\right)_{2} \mathrm{CH}_{3} ; \mathrm{R}_{2}, \mathrm{R}_{3}=\mathrm{H}$ & $11 \pm 2.1^{[b]}$ \\
\hline 1h & $\mathrm{R}=\mathrm{H} ; \mathrm{R}_{1}=\left(\mathrm{CH}_{2}\right)_{2} \mathrm{CONHPh} ; \mathrm{R}_{2}, \mathrm{R}_{3}=\mathrm{H}$ & n.a. \\
\hline $1 \mathbf{i}$ & $\mathrm{R}=\mathrm{H} ; \mathrm{R}_{1}=\mathrm{Ph} ; \mathrm{R}_{2}, \mathrm{R}_{3}=\mathrm{H}$ & $6.1 \pm 0.9^{[b]}$ \\
\hline $2 a$ & $\mathrm{R}=\mathrm{CH}_{3} ; \mathrm{R}_{1}=\mathrm{Br} ; \mathrm{R}_{2}, \mathrm{R}_{3}=\mathrm{H}$ & $25.6 \pm 1.2^{[\mathrm{b}]}$ \\
\hline $2 b$ & $\mathrm{R}=\mathrm{H} ; \mathrm{R}_{1}, \mathrm{R}_{2}, \mathrm{R}_{3}=\mathrm{CH}_{3}$ & $8.9 \pm 1.1^{[\mathrm{b}]}$ \\
\hline 3 & $\mathrm{R}, \mathrm{R}_{1}=\mathrm{H} ; \mathrm{R}_{2}, \mathrm{R}_{3}=\mathrm{CH}_{2} \mathrm{Ph}$ & n.a. \\
\hline 4 & $\mathrm{R}, \mathrm{R}_{1}, \mathrm{R}_{3}=\mathrm{H} ; \mathrm{R}_{2}=\mathrm{CH}_{2} \mathrm{CONH}\left(\mathrm{CH}_{2}\right)_{2} \mathrm{Ph}$ & $17.3 \pm 1.3^{[b]}$ \\
\hline 5 & - & $3.5 \pm 5.6^{[b]}$ \\
\hline 6 & - & $11.5 \pm 0.8^{[b]}$ \\
\hline
\end{tabular}

[a] STAT3 inhibition: $\mathrm{IC}_{50}=15.8 \pm 0.6 \mu \mathrm{M}$; STAT1 inhibition: $\mathrm{IC}_{50}>50 \mu \mathrm{M}$. ${ }^{\mathrm{b}]}$ STAT3 inhibition: $\mathrm{IC}_{50}>30 \mu \mathrm{M}$.

[c] STAT3 inhibition: $\mathrm{IC}_{50}=25.1 \pm 2.6 \mu \mathrm{M}$; STAT1 inhibition: $\mathrm{IC}_{50}=15.9 \pm 2.0 \mu \mathrm{M}$. n.a.: not active.

Finally, we investigated the importance of the thiadiazole ring ( 5 and 6 ) through the exploration of the function of the $\mathrm{SO}_{2}$ group and of the nitrogen atoms: The results of the AlphaScreen-based assay indicated that these moieties play a key role in the interaction with the STAT3-SH2 domain.

Overall, our data seem to indicate that this class of benzothiadiazole derivatives is characterized by an extremely "tight" SAR: Most of the modifications applied to the scaffold of compound 1 resulted in a considerable loss of activity, with the sole exception of $\mathbf{1 d}$, which retained a partial inhibitory effect.

Since from the literature it is known that some benzothiadiazoles could covalently bind to proteins [26], an in silico prediction to evaluate whether the proposed derivatives were pan-assay interference compounds (PAINS) was performed by submitting their structures to five on-line services (FAF-Drugs4 [27], PAINS remove [28], SmartsFilter, (http://pasilla.health.unm.edu/tomcat/biocomp/ smartsfilter), SwissADME [29], and Zinc Patterns (http://zinc15.docking.org/patterns/home/)). Three of them (SmartsFilter, SwissADME, and Zinc Patterns) identified compounds $\mathbf{1}, \mathbf{1} \mathbf{a}-\mathbf{i}$, and $\mathbf{2} \mathbf{a}$ as potential PAINS (see Table S6).

This result was experimentally confuted, at least for compound 1, because it was found to act as a selective STAT3 inhibitor with an $\mathrm{IC}_{50}$ of $15.8 \pm 0.6 \mu \mathrm{M}$, which was significantly lower than the $\mathrm{IC}_{50}$ shown versus STAT1 $(>50 \mu \mathrm{M})$. This selectivity was remarkable considering the high similarity and identity of both STAT1 and STAT3, for the SH2 domain in particular (73.5\% sequence similarity and $56.1 \%$ sequence identity, calculated by EMBOSS Needle [30]).

Furthermore, to gain insight into the activity of compound 1, its interaction with the cysteine residues located in the vicinities of the $\mathrm{SH} 2$ domain (Figure 3) was investigated and evaluated by an AlphaScreen-based assay using different mutants (Table 3). 
Table 3. Sensitivity of single-mutated STAT3 proteins (Cys468, Cys542, Cys550, Cys687, and Cys712) to compound 1. SH2 binding to the phosphotyrosine peptide was assessed by the AlphaScreen assay. The means \pm SD were calculated from triplicate experiments.

\begin{tabular}{cccc}
\hline \multicolumn{4}{c}{ Compound 1 vs. STAT3 } \\
\hline Mutated Cys & IC $_{\mathbf{5 0}}(\boldsymbol{\mu M})$ & Mutated Cys & IC $_{\mathbf{5 0}}(\boldsymbol{\mu M})$ \\
\hline WT & $15.8 \pm 0.6$ & Cys550A & $>30$ \\
Cys468A & $>30$ & Cys687A & $>30$ \\
Cys542A & $>30$ & Cys712A & $>30$ \\
\hline
\end{tabular}

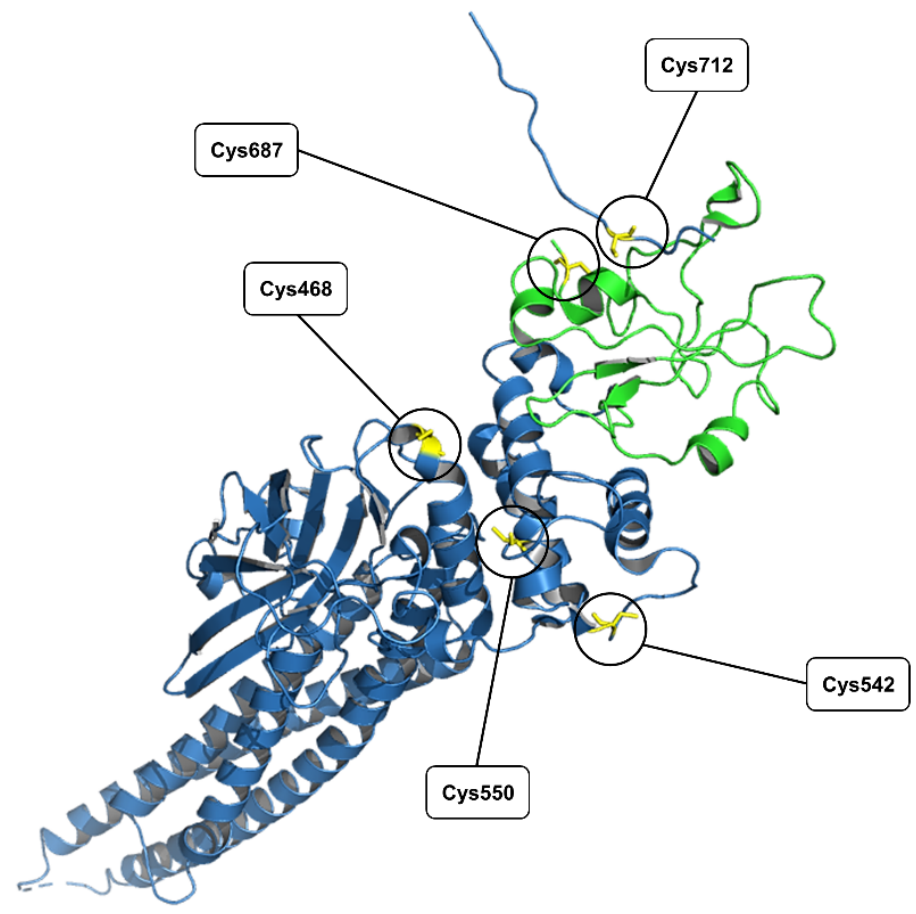

Figure 3. Ribbon diagram of STAT3 (blue), with the $\mathrm{SH} 2$ domain in green and the mutated cysteine residues in yellow (Protein Data Bank (PDB) ID 1BG1).

Compound 1 was inactivated by the addition of an excess amount of cysteine into the assay medium (see Table S7). Moreover, the point mutations of Cys468, Cys542, Cys550, Cys687, or Cys712 in STAT3 conferred resistance to the compound (see Table S8), suggesting that each cysteine residue partially contributes to the inhibition mediated by the molecule.

Though STAT3 contains twelve cysteine residues, the assays were performed only on clones bearing mutations on the five cysteines located near the STAT3-SH2 domain. Therefore, we cannot exclude the possibility that other cysteines may be involved in the interaction with compound 1 .

Considering the affinity of compound $\mathbf{1}$ for STAT3 wild-type, we decided to explore its mechanism of interaction with cysteines by means of analytical studies.

In order to analyze the binding mode of compound $\mathbf{1}$ to the pockets containing the mutated cysteine residues, a molecular docking study was carried out. In particular, we applied the same protocol used for the virtual screening, but, in this case, the grid maps were calculated by selecting the atoms included in a sphere of $12 \AA$ radius that were centered on each cysteine residue. The so-obtained complexes were optimized with the same minimization protocol employed for the preparation of the STAT3 crystal structure (30,000 steps of conjugate gradients minimization). For a better analysis of the poses, the distances between the cysteine sulfur and the two hypothetical reactive centers (the methyl in 5 and the aromatic carbon in 4) of compound $\mathbf{1}$ were evaluated. The results in Table S9 show that only the complex with Cys712 seems to have the suitable prerequisites in terms of distances to 
the reactive centers (4.70 and $4.95 \AA$ for $\mathrm{CH}_{3}-\mathrm{S}$ and $\mathrm{CH}-\mathrm{S}$, respectively; see Figure S72) and docking energy $(-5.93 \mathrm{Kcal} / \mathrm{mol})$, even if the latter parameter must be taken into account with caution because it was calculated by molecular mechanics. The complex with Cys550 also seemed to have the right distances to react with compound $\mathbf{1}$ (3.64 and $5.13 \AA$ for $\mathrm{CH}_{3}-\mathrm{S}$ and $\mathrm{CH}-\mathrm{S}$, respectively); however, the interaction energy was found to be significantly worse than that of the complex with Cys712 $(-3.52$ versus $-5.93 \mathrm{Kcal} / \mathrm{mol})$. Unfortunately, this kind of behavior could not be confirmed by the experimental data; this was probably due to the intrinsic problem afflicting all docking calculations that could only evaluate the physicochemical and steric complementarity of two interacting partners and not the reactivity of the atoms.

\subsection{Analytical Studies}

\subsubsection{MS, UV, and LC Studies}

MS studies revealed that compound 1 reacts with glutathione (GSH, used as a model for cysteine-containing peptides) to generate stable covalent adducts. Since no adducts were detectable at the incubation starting point, such reactions did not take place during sample transfer into the MS analyzer. Similar approaches have already been used to identify reactive intermediates by MS studies [31]. The reaction was $\mathrm{pH}$-dependent and required a neutral or basic $\mathrm{pH}$ to take place, whereas no reactivity was observed at an acidic $\mathrm{pH}$ (Figure 4).

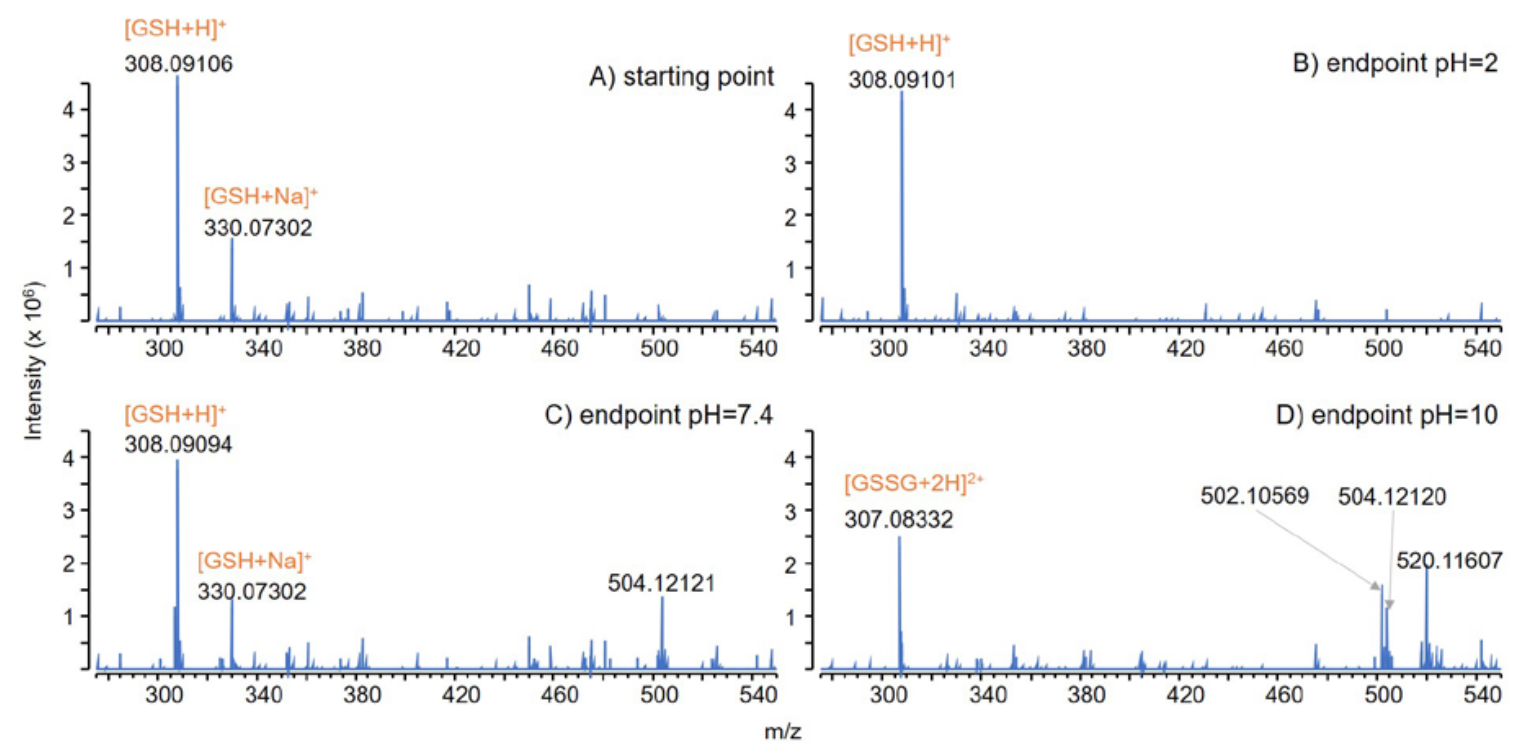

Figure 4. MS spectra of glutathione (GSH) incubated with compound $\mathbf{1}$ as recorded at incubation starting point (A), at incubation endpoint in a $\mathrm{pH} 2$ buffer (B), at incubation endpoint in a $\mathrm{pH} 7.4$ buffer (C), and at incubation endpoint in a pH 10 buffer (D).

The absence of reactivity at the acidic $\mathrm{pH}$ can be explained on one hand by the $\mathrm{pH}$-dependent nucleophilicity of GSH [32] and on the other hand by the deprotonation of compound $\mathbf{1}$ occurring at a neutral/basic $\mathrm{pH}(\mathrm{pKa}=6.88 \pm 0.03)$ [22], which can lead to structure rearrangements that possibly contribute to an increased reactivity towards GSH. However, the methyl groups seem fundamental for the covalent reaction, since no adducts were detectable upon incubation of GSH with compound 1d, which was the second most active compound according to the results reported in Table 2.

At a neutral pH (Figure 4C), a single adduct was detectable at the reaction endpoint $(504.12121 \mathrm{~m} / \mathrm{z})$, whereas at a basic pH (Figure 4D), three signals at 502.10569, 504.12120, and $520.11607 \mathrm{~m} / \mathrm{z}$ were detected along with the complete oxidation of GSH to its dimer GSSG (i.e., the conversion of the singly charged GSH ion at $308.09106 \mathrm{~m} / \mathrm{z}$ to the doubly charged GSSG ion at $307.08332 \mathrm{~m} / \mathrm{z}$ ). 
The signals at 502.10569,504.12120, and 520.11607 $\mathrm{m} / \mathrm{z}$ were all within $1 \mathrm{ppm}$ from the theoretical $m / z$ values expected for singly charged ions of molecules $\mathrm{C}_{18} \mathrm{H}_{25} \mathrm{~N}_{5} \mathrm{O}_{8} \mathrm{~S}_{2}, \mathrm{C}_{18} \mathrm{H}_{23} \mathrm{~N}_{5} \mathrm{O}_{8} \mathrm{~S}_{2}$, and $\mathrm{C}_{18} \mathrm{H}_{25} \mathrm{~N}_{5} \mathrm{O}_{9} \mathrm{~S}_{2}$, respectively.

Interestingly, at $\mathrm{pH} 10$, the adducts were also detected at the incubation starting point if compound 1 was added before GSH into the buffer (Figure 5A), but not if GSH (Figure 5B) or $\mathrm{Na}_{2} \mathrm{~S}_{2} \mathrm{O}_{5}$ (Figure 5C) were added into the buffer before compound $\mathbf{1}$.

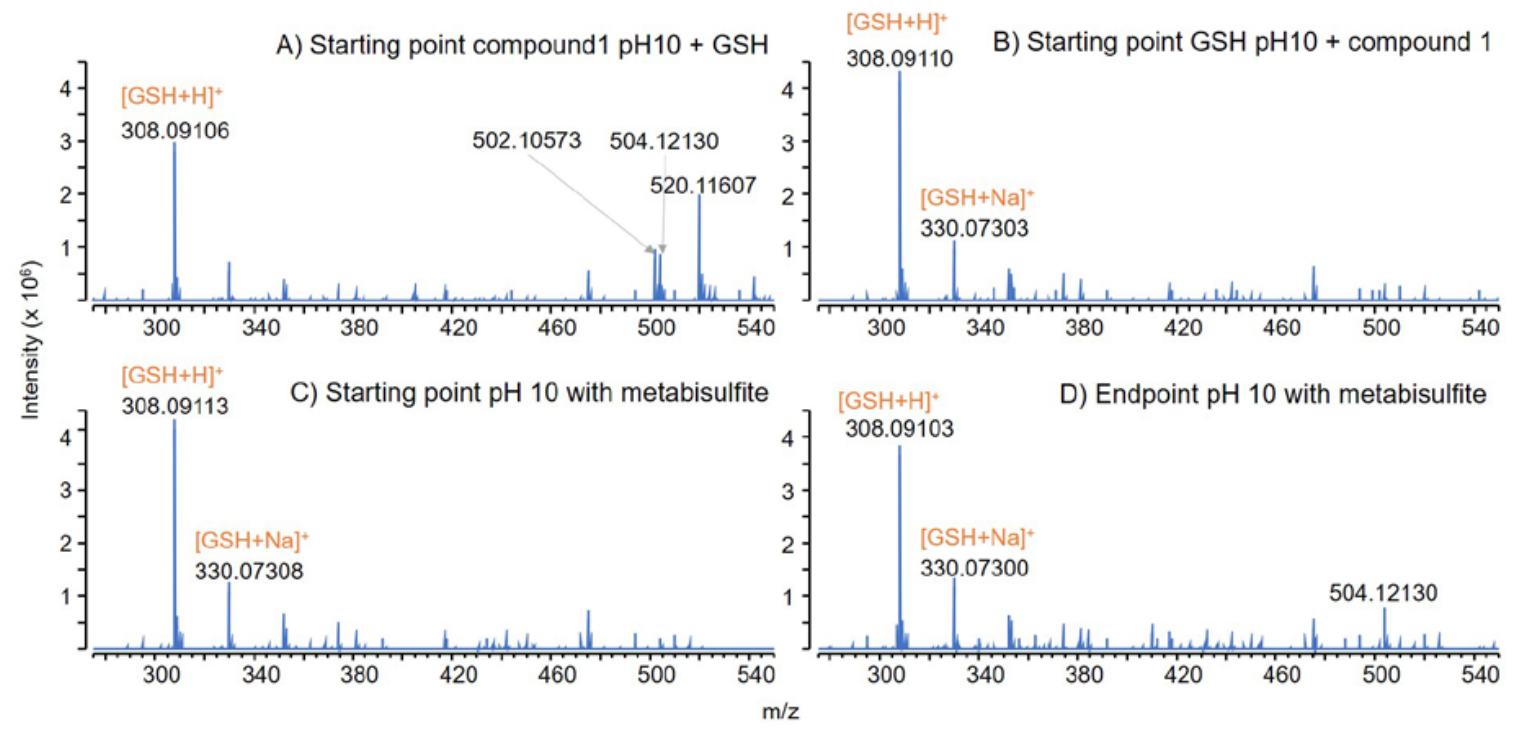

Figure 5. MS spectra at the reaction starting point for a 1:1 GSH:compound $\mathbf{1}$ mixture incubated at $\mathrm{pH}$ 10 (spectra A and B). Samples were prepared by adding compound 1 (spectrum A) or GSH (spectrum

B) as the first reagent. MS spectra at the incubation starting point (spectrum C) and endpoint (spectrum

D) for a 1:1 GSH:compound 1 mixture incubated at $\mathrm{pH} 10$ with $\mathrm{Na}_{2} \mathrm{~S}_{2} \mathrm{O}_{5}$ in the buffer.

Since GSH is an antioxidant, we speculated on the involvement of oxidation steps for the formation of adducts. To address such a hypothesis, the experiments were repeated in a buffer containing $\mathrm{Na}_{2} \mathrm{~S}_{2} \mathrm{O}_{5}$, which had similar effect of GSH at the incubation starting point (Figure 5C) and prevented the formation of adducts at 502.10569 and $520.11607 \mathrm{~m} / \mathrm{z}$ at the incubation endpoint (Figure 5D), suggesting that such adducts are generated only in oxidizing conditions.

On the contrary, the adduct at $504.12130 \mathrm{~m} / \mathrm{z}$ was detectable at the incubation endpoint, despite $\mathrm{Na}_{2} \mathrm{~S}_{2} \mathrm{O}_{5}$ addition (Figure 5D).

Consistently with MS data, LC-UV experiments detected a single adduct when compound 1 was incubated with GSH and $\mathrm{Na}_{2} \mathrm{~S}_{2} \mathrm{O}_{5}$ (i.e., chromatographic peak at $\mathrm{RT}=8.7 \mathrm{~min}$, Figure $6 \mathrm{~B}$ ), whereas multiple peaks were generated if no antioxidants were added into the buffer (Figure 6C).

$\mathrm{Na}_{2} \mathrm{~S}_{2} \mathrm{O}_{5}$ also prevented the complete consumption of compound $\mathbf{1}$ (Figure 5B), thus confirming that oxidizing conditions trigger a faster reaction rate.

Moreover, despite MS experiments detecting an adduct at $504.12125 \pm 0.00006 \mathrm{~m} / \mathrm{z}$, both with and without $\mathrm{Na}_{2} \mathrm{~S}_{2} \mathrm{O}_{5}$, the corresponding chromatograms had no common peaks. This means that oxidizing and non-oxidizing conditions lead to the formation of adducts with different structures but the same elemental composition.

This hypothesis was also supported by the UV spectra collected for the corresponding reaction batches. As reported in Figure 6, the UV spectra at the reaction endpoint look alike for reactions buffered at $\mathrm{pH} 7.4$ or $\mathrm{pH} 10$ with $\mathrm{Na}_{2} \mathrm{~S}_{2} \mathrm{O}_{5}$, with no shifts compared to the starting point (data not shown). On the contrary, the incubation at $\mathrm{pH} 10$ without $\mathrm{Na}_{2} \mathrm{~S}_{2} \mathrm{O}_{5}$ was only found to have a similar shape at the starting point, while a significant shift was observed at the reaction endpoint (Figure 7). 


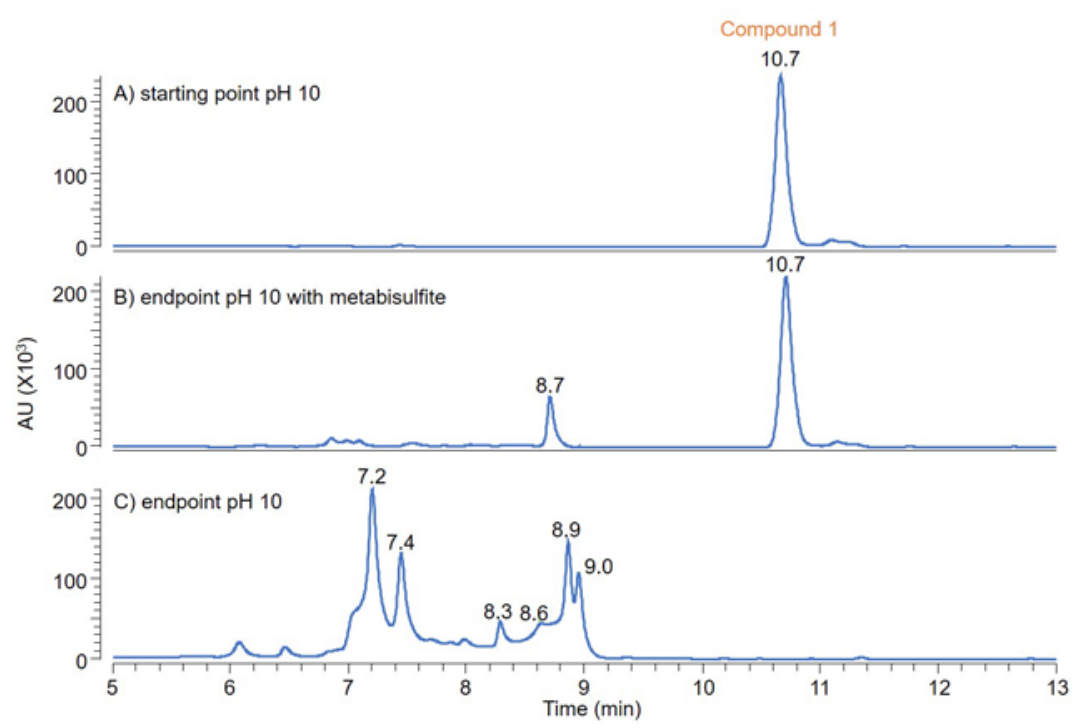

Figure 6. Chromatograms of GSH incubated with compound $\mathbf{1}$ as recorded at incubation starting point (A), at incubation endpoint in a pH 10 buffer containing $\mathrm{Na}_{2} \mathrm{~S}_{2} \mathrm{O}_{5}(\mathbf{B})$, and at incubation endpoint in a $\mathrm{Na}_{2} \mathrm{~S}_{2} \mathrm{O}_{5}$-free $\mathrm{pH} 10$ buffer $(\mathbf{C})$.

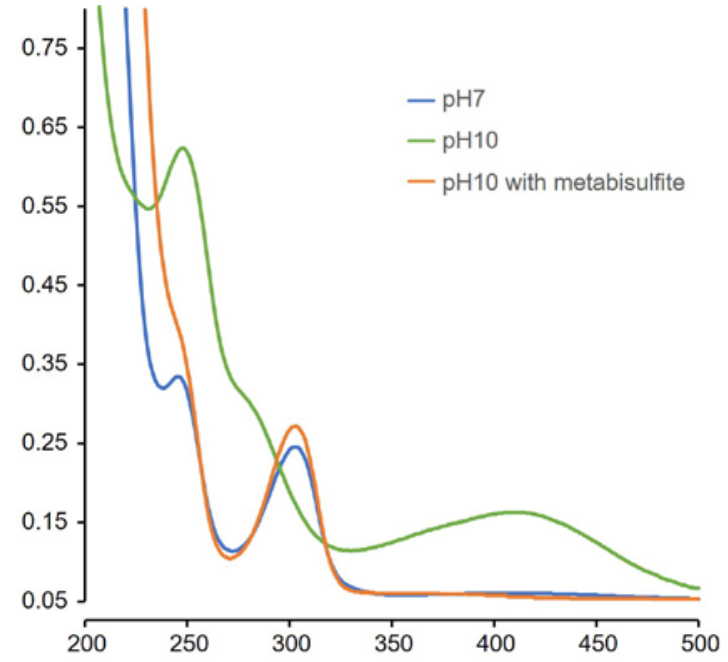

Figure 7. UV spectra at the endpoint of the reaction between GSH and compound 1. Reaction was buffered at $\mathrm{pH} 7.4$ (blue line), $\mathrm{pH} 10$ (green line), or $\mathrm{pH} 10$ with $\mathrm{Na}_{2} \mathrm{~S}_{2} \mathrm{O}_{5}$ (orange line).

The reaction mechanism in Figure 8 accounts for all the observations described above.

Specifically, the overall mechanism requires a neutral-to-basic $\mathrm{pH}$ for compound $\mathbf{1}$ deprotonation to generate adducts. All included oxidation steps are dependent on the basic $\mathrm{pH}$ activation of compound 1, like with catechol [33], and provide the generation of reactive intermediates similar to quinones and quinone-methides that are able to covalently react with GSH [34-36]. The final products VIb and VIIa are generated only after the oxidative rearrangement of compound $\mathbf{1}$ and have molecular formulas in agreement with the MS signals at 502 and $520 \mathrm{~m} / \mathrm{z}$, found only in reaction batches without antioxidants. The products IVa and IIb were found to have the same molecular formula, which was in agreement with the signal at $504 \mathrm{~m} / \mathrm{z}$ that was found in reaction batches with or without antioxidants. However, consistently with LC experiments, the products IVa and IIb were found to have different structures and formation mechanisms: IVa was found to be generated after compound $\mathbf{1}$ oxidation, while the formation of IIb was not found to require the oxidation of compound 1. Interestingly, such mechanism is not specific for the class of compounds since it was only observed for compound $\mathbf{1}$. The removal of 
the methyl groups led to compounds that were unable to covalently react with glutathione, despite some of them still being capable of inhibiting STAT3 activity (e.g., compound 1d; see Table 2).

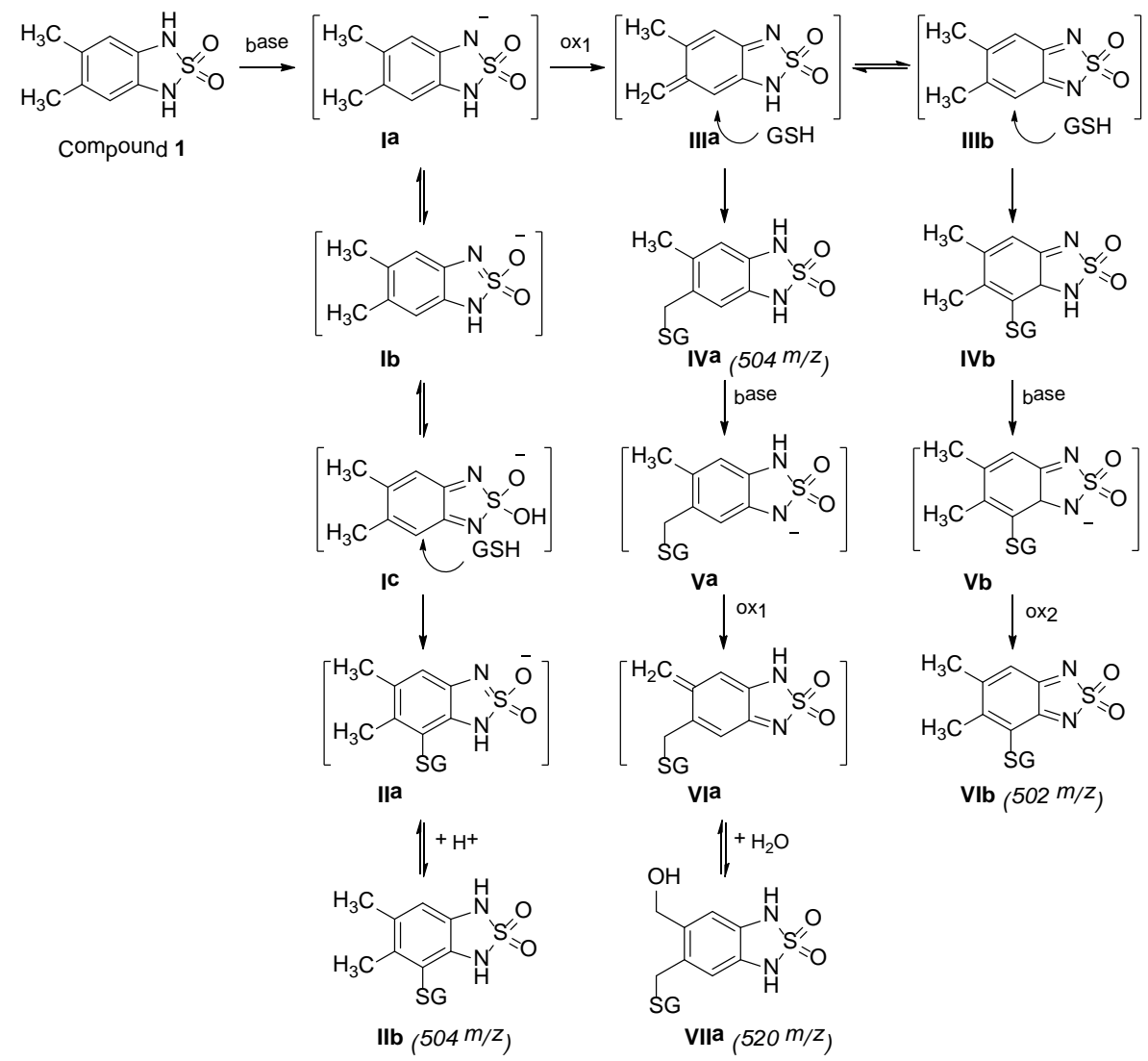

Figure 8. Proposed reaction mechanisms for the generation of compound 1-glutathione adducts. Group SG indicates covalently attached glutathione via thioether linkage.

\subsection{2. ${ }^{1} \mathrm{H}-\mathrm{NMR}$ Analysis}

With the aim of confirming the stated hypotheses, NMR studies were performed in the experimental conditions previously considered for the MS analysis in the absence or in the presence of GSH. Actually, few NMR studies concerning covalent interactions between GSH/STAT proteins and small molecules have been reported. In one case [37], the authors exploited the presence of fluorine atoms on the studied compounds and used ${ }^{19} \mathrm{~F}-\mathrm{NMR}$ spectroscopy, which has the advantage of simple spectra with a wide spread of resonances.

In our case, we used ${ }^{1} \mathrm{H}-\mathrm{NMR}$ spectroscopy even though it is known that GSH, like other small peptides, presents a great conformational variability, also depending on the $\mathrm{pH}$, that influences its ionization state [38]; consequently, its ${ }^{1} \mathrm{H}-\mathrm{NMR}$ spectra could appear quite complex.

Therefore, to study the interaction of compound 1 with the model peptide GSH, we decided to perform a comparison, at different times, of the spectra of compound 1 and of GSH alone with the spectrum of a mixture of them at $\mathrm{pH} 10$ and $37^{\circ} \mathrm{C}$. These conditions were chosen because they proved to be optimal for the interaction between the two compounds in the MS investigations. Moreover, in order to make the NMR study easier, we decided to add $\mathrm{Na}_{2} \mathrm{~S}_{2} \mathrm{O}_{5}$ to the mixture to reduce the number of adducts that could potentially derive from the reactions between compound $\mathbf{1}$ and GSH. The use of this reducing agent made the MS spectra less complex, mainly showing a $504[\mathrm{M}+\mathrm{H}]^{+}$ ion (Figure 5D) corresponding to few hypothetical structures (IIb and IVa; Figure 8); in the same conditions, the LC chromatogram revealed essentially one peak at $8.7 \mathrm{~min}$, even if this analysis showed only a reduced transformation of the starting compound $\mathbf{1}$ at the incubation endpoint (Figure 6B). 
Moreover, the addition of $\mathrm{Na}_{2} \mathrm{~S}_{2} \mathrm{O}_{5}$ should have prevented the presence of interfering NMR resonances due to the formation of oxidized GSSG.

Though this study did not demonstrate the formation of the expected compounds (see discussion in Supplementary Materials and Figures S72-S74), we believe that the NMR outcomes cannot disprove the results obtained by MS spectroscopy.

\section{Experimental Section}

\subsection{Computational Methods}

The structural coordinates of STAT3, co-crystallized with a DNA fragment, were downloaded from the Protein Data Bank (PDB ID 1BG1) [19]. The protein was dimerized by applying the transformation matrix, as shown in the PDB file, and the model was completed by the addition of the hydrogens in two steps: (1) to STAT3, applying the algorithm for proteins, and (2) to DNA, applying the algorithm for nucleic acids. In both cases, we used the features included in the VEGA ZZ package [39]. Atom charges (Gasteiger-Marsili method) [40] and potentials (CHARMM 22 for proteins and nucleic acids) [41,42] were assigned to the obtained structure. Finally, the model was optimized by a conjugate gradient minimization (30,000 steps) to reduce the high-energy steric interactions. In order to preserve the experimental data, atom constraints were applied to protein and DNA backbones. This step was carried out by NAMD 2.13 [43], which was integrated in the VEGA ZZ graphic environment. To perform virtual screening calculations, the following databases were chosen: AKos (AKos Consulting \& Solutions GmbH, Steinen, Germany; 544,391 molecules), ChemPDB (4009), ChemBank (Broad Institute, Cambridge, MA, USA; 2344), KEGG (Kyoto Encyclopedia of Genes and Genomes, Kanehisa Laboratories, Kyoto, Japan; 10005), NCI's Anti-HIV (National Cancer Institute, National Institute of Health, USA; 42689), and NCI (National Cancer Institute, National Institute of Health, USA; 15237). These databases are available for free at the mirror site of Ligand.info (http://biophysics.med.jhmi.edu/ \{\}yliu120/dockingdatabase.html; the original database site is no longer available) [44], which includes collections of compounds for virtual screening. These structures are already converted to 3D and fully optimized by molecular mechanics. Nevertheless, all molecules were pre-processed setting their ionization state at a physiological $\mathrm{pH}$, and the resulting structures were optimized and refined by PM7 semi-empirical method, as implemented in MOPAC 2016. To perform this calculation, the WarpEngine technology implemented in VEGA ZZ [45] was used, reducing the computational time to few tens of minutes for the whole dataset through the distribution of the MOPAC calculation on a network of PCs. In more detail: Three blade servers equipped with two CPUs, each of Intel Xeon E5 class, were used for a total of 52 physical cores and 104 threads. The virtual screening was carried out by the GriDock software, which was especially designed to run on high performance computing systems (HPC) and distributed computer resources (GRID) as front-end to the well-known AutoDock 4 package [20]. Specifically, GriDock is able to extract each molecule from a database and perform a docking calculation through AutoDock 4 . Though it is currently possible to perform screenings with faster and more efficient programs, we preferred to spend more time on the calculation because we had already obtained good results with AutoDock in previous studies on STAT3. Before running GriDock, a single STAT3 monomer was considered, and the grid maps, required to evaluate docking scores, were calculated by selecting the atoms included in a sphere of $12 \AA$ radius centered on the phosphorylated Tyr-705 (PTR-705 in the PDB file). This pocket represented a possible hot spot of interaction with STAT3 for ligands, since it is known to play a pivotal role in STAT3 dimerization and activation. This process was carried out by AutoGrid 4 interfaced to VEGA ZZ. The compounds of the considered databases were docked by GriDock/AutoDock using the genetic-algorithm search and generating ten possible solutions. 


\subsection{Chemistry}

\subsubsection{Materials and Methods}

All starting materials, chemicals, and solvents were purchased from commercial suppliers (Sigma-Aldrich-Merck, St. Louis, MI, USA; FluoroChem, Hadfield, UK) and used as received. Anhydrous solvents were utilized without further drying. Aluminum-backed silica gel 60 plates (0.2 mm; Merck, Darmstadt, Germany) were used for analytical thin-layer chromatography (TLC) to follow the course of the reactions. Silica gel $60(40-63 \mu \mathrm{m}$; Merck) was used for the purification of intermediates and final compounds through flash column chromatography. Melting points were determined in open capillary tubes with a Stuart SMP30 Melting Point Apparatus (Cole-Parmer Stuart, Stone, UK) and are uncorrected. ${ }^{1} \mathrm{H}$ and ${ }^{13} \mathrm{C}-\mathrm{NMR}$ spectra were acquired at ambient temperature with a Varian Oxford $300 \mathrm{MHz}$ instrument (Varian, Palo Alto, CA, USA), operating at $300 \mathrm{MHz}$ for ${ }^{1} \mathrm{H}$ and $75 \mathrm{MHz}$ for ${ }^{13} \mathrm{C}$. Chemical shifts are expressed in ppm ( $\delta$ ) from tetramethylsilane (TMS) resonance in the indicated solvent (TMS: $\delta=0.0 \mathrm{ppm}$ ), while $J$-couplings are given in hertz. All the spectra are reported in the Supplementary Materials. The purity of the tested compounds was assessed by means of elemental analysis using a EuroVector EA 3000 CHNS-O analyzer (EuroVector, Pavia, Italy). All experimental values are within $\pm 0.40 \%$ of the theoretical predictions, indicating a $\geq 95 \%$ purity.

\subsubsection{Synthetic Procedures}

\section{5,6-Dimethyl-1H,3H-2,1,3-benzothiadiazole-2,2-dioxide, 1}

Procedure A: To a solution of 4,5-dimethyl-1,2-phenylenediamine (100 mg, $0.73 \mathrm{mmol})$ in dry diglyme $(0.75 \mathrm{~mL})$ under reflux, sulfamide $(86 \mathrm{mg}, 0.89 \mathrm{mmol})$ dissolved in dry diglyme $(0.73 \mathrm{~mL})$ was slowly added. The mixture was stirred for $10 \mathrm{~min}$ at $160^{\circ} \mathrm{C}$. After cooling, the dark brown mixture was diluted with ice- $\mathrm{H}_{2} \mathrm{O}$ and extracted with EtOAc $(3 \times 5 \mathrm{~mL})$. The organic phase was washed repeatedly with cold $\mathrm{H}_{2} \mathrm{O}$ to remove the diglyme. Then, it was treated with $\mathrm{Na}_{2} \mathrm{SO}_{4}$, filtered, and evaporated under reduced pressure. The crude product was purified by flash column chromatography (cyclohexane/EtOAc 8:2) to obtain $\mathbf{1}$ as a brownish solid. Yield: 50\%. TLC (cyclohexane/EtOAc 8:2): $\mathrm{R}_{\mathrm{f}}$ : 0.36. Mp: $148{ }^{\circ} \mathrm{C} .{ }^{1} \mathrm{H}-\mathrm{NMR}\left(300 \mathrm{MHz}\right.$, acetone- $\left.d_{6}\right): \delta 9.25(\mathrm{~s}, 2 \mathrm{H}, \mathrm{NH}), 6.72(\mathrm{~s}, 2 \mathrm{H}, \mathrm{ArH}), 2.18(\mathrm{~s}, 6 \mathrm{H}$, $\left.\mathrm{CH}_{3}\right)$ ppm. ${ }^{13} \mathrm{C}-\mathrm{NMR}\left(75 \mathrm{MHz}, \mathrm{D}_{2} \mathrm{O}\right): \delta 134.6,127.0,111.1,18.4 \mathrm{ppm}$. Anal. calcd (\%) for $\mathrm{C}_{8} \mathrm{H}_{10} \mathrm{~N}_{2} \mathrm{O}_{2} \mathrm{~S}$ : C, 48.47; H, 5.08; N, 14.13; S, 16.17; found: C, 48.21; H, 5.03; N, 14.67; S, 16.34 .

\section{H,3H-2,1,3-Benzothiadiazole-2,2-dioxide, 1a}

Benzene-1,2-diamine was reacted for $1.5 \mathrm{~h}$ using Procedure A; the purification was performed by flash column chromatography (cyclohexane/EtOAc 6:4) to afford the compound as a dark yellow solid. Yield: 88\%. TLC (cyclohexane/EtOAc 6:4): $\mathrm{R}_{\mathrm{f}}$ : 0.23. Mp: 171-173 ${ }^{\circ} \mathrm{C} .{ }^{1} \mathrm{H}-\mathrm{NMR}\left(300 \mathrm{MHz}, \mathrm{CD}_{3} \mathrm{OD}\right.$ ):

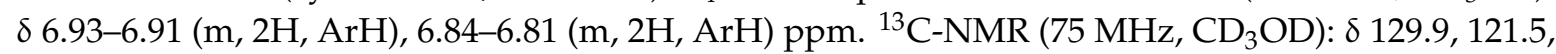
110.2 ppm. Anal. calcd (\%) for $\mathrm{C}_{6} \mathrm{H}_{6} \mathrm{~N}_{2} \mathrm{O}_{2} \mathrm{~S}: \mathrm{C}, 42.34 ; \mathrm{H}, 3.55 ; \mathrm{N}, 16.46 ; \mathrm{S}, 18.84$; found: $\mathrm{C}, 41.98 ; \mathrm{H}$, $3.59 ; \mathrm{N}, 16.35 ; \mathrm{S}, 18.75$.

\section{5-Methyl-1H,3H-2,1,3-benzothiadiazole-2,2-dioxide, 1b}

4-methylbenzene-1,2-diamine was reacted for $1.5 \mathrm{~h}$ using Procedure A; the crude residue was purified by flash column chromatography (DCM/MeOH 98:2) to give a dark red solid. Yield: $55 \%$. TLC (DCM/MeOH 9:1): $\mathrm{R}_{\mathrm{f}}: 0.54 . \mathrm{Mp}: 157{ }^{\circ} \mathrm{C} .{ }^{1} \mathrm{H}-\mathrm{NMR}\left(300 \mathrm{MHz}, \mathrm{CD}_{3} \mathrm{OD}\right): \delta 6.73-6.66$ (m, 3H, ArH), 2.28 (s, 3H, $\mathrm{CH}_{3}$ ) ppm. ${ }^{13} \mathrm{C}-\mathrm{NMR}$ (75 MHz, $\mathrm{CD}_{3} \mathrm{OD}$ ): $\delta$ 131.6, 130.1, 127.5, 121.8, 110.8, 110.2, 19.9 ppm. Anal. calcd (\%) for $\mathrm{C}_{7} \mathrm{H}_{8} \mathrm{~N}_{2} \mathrm{O}_{2} \mathrm{~S}: \mathrm{C}, 45.64 ; \mathrm{H}, 4.38 ; \mathrm{N}, 15.21 ; \mathrm{S}, 17.41$; found: $\mathrm{C}, 45.11 ; \mathrm{H}, 4.51 ; \mathrm{N}, 14.96$; S, 17.25 . 
5-(Trifluoromethyl)-1H,3H-2,1,3-benzothiadiazole-2,2-dioxide, 1c

4-(trifluoromethyl)benzene-1,2-diamine was reacted for $1.5 \mathrm{~h}$ using Procedure $\mathrm{A}$; the purification was performed by flash column chromatography (DCM/MeOH 9:1) to give a white solid. Yield: $66 \%$. TLC (DCM/MeOH 9:1): $\mathrm{R}_{\mathrm{f}}: 0.19$. Mp: $143^{\circ} \mathrm{C} .{ }^{1} \mathrm{H}-\mathrm{NMR}\left(300 \mathrm{MHz}, \mathrm{CD}_{3} \mathrm{OD}\right): \delta 7.23$ (dd, $J=8.2,2.0 \mathrm{~Hz}$, $1 \mathrm{H}, \mathrm{ArH}), 7.06(\mathrm{~d}, J=2.0 \mathrm{~Hz}, 1 \mathrm{H}, \mathrm{ArH}), 6.94(\mathrm{~d}, J=8.2 \mathrm{~Hz}, 1 \mathrm{H}, \mathrm{ArH}) \mathrm{ppm} .{ }^{13} \mathrm{C}-\mathrm{NMR}\left(75 \mathrm{MHz}, \mathrm{CD}_{3} \mathrm{OD}\right)$ : $\delta 132.61,129.65,123.38,123.06,123.00,118.66(\mathrm{q}, J=4.2 \mathrm{~Hz}), 109.34,106.41(\mathrm{q}, J=4.2 \mathrm{~Hz}) \mathrm{ppm}$. Anal. calcd (\%) for $\mathrm{C}_{7} \mathrm{H}_{5} \mathrm{~F}_{3} \mathrm{~N}_{2} \mathrm{O}_{2} \mathrm{~S}: \mathrm{C}, 35.30 ; \mathrm{H}, 2.12 ; \mathrm{N}, 11.76 ; \mathrm{O}, 13.43 ; \mathrm{S}, 13.46$; found: $\mathrm{C}, 35.61 ; \mathrm{H}, 2.17 ; \mathrm{N}$, $11.94 ; \mathrm{S}, 13.78$.

5-Nitro-1H,3H-2,1,3-benzothiadiazole-2,2-dioxide, 1d

4-nitrobenzene-1,2-diamine was reacted for $1.5 \mathrm{~h}$ using Procedure $\mathrm{A}$; the residue was purified by flash column chromatography (DCM/MeOH 9:1) to give a red solid. Yield: 50\%. TLC (DCM/MeOH 9:1): $\mathrm{R}_{\mathrm{f}}: 0.15 \mathrm{Mp}: 190^{\circ} \mathrm{C} .{ }^{1} \mathrm{H}-\mathrm{NMR}\left(300 \mathrm{MHz}, \mathrm{CD}_{3} \mathrm{OD}\right): \delta 7.66(\mathrm{dd}, J=8.7,2.5 \mathrm{~Hz}, 1 \mathrm{H}, \mathrm{ArH}), 7.38(\mathrm{~d}$, $J=2.5 \mathrm{~Hz}, 1 \mathrm{H}, \mathrm{ArH}), 6.53(\mathrm{~d}, J=8.7 \mathrm{~Hz}, 1 \mathrm{H}, \mathrm{ArH}) \mathrm{ppm} .{ }^{13} \mathrm{C}-\mathrm{NMR}\left(75 \mathrm{MHz}, \mathrm{CD}_{3} \mathrm{OD}\right): \delta 144.2,140.1$, 133.4, 119.6, 108.9, 104.3 ppm. Anal. calcd (\%) for $\mathrm{C}_{6} \mathrm{H}_{5} \mathrm{~N}_{3} \mathrm{O}_{4} \mathrm{~S}: \mathrm{C}, 33.49 ; \mathrm{H}, 2.34 ; \mathrm{N}, 19.53 ; \mathrm{O}, 29.74 ; \mathrm{S}$, 14.90; found: C, 33.74; H, 2.38; N, 19.41; S, 14.51 .

5-Chloro- $N$-[(2,4-dimethoxyphenyl)methyl]-2-nitroaniline, 7

Procedure B: A mixture of 2,4-dichloro-1-nitrobenzene (191 mg, $1 \mathrm{mmol})$, 2,4-dimethoxybenzylamine (334 mg, $2 \mathrm{mmol}$ ), and isopropanol $(2 \mathrm{~mL})$ was heated at reflux for $16 \mathrm{~h}$. After cooling, the reaction was diluted with $\mathrm{H}_{2} \mathrm{O}(4 \mathrm{~mL})$ and extracted with EtOAc $(2 \times 4 \mathrm{~mL})$. The collected organic layers were washed with $0.5 \mathrm{M} \mathrm{HCl}(1 \times 5 \mathrm{~mL})$ and then dried over anhydrous $\mathrm{Na}_{2} \mathrm{SO}_{4}$, filtered, and concentrated in vacuo. The crude residue was purified by recrystallization from EtOH to obtain intermediate 7 as an orange solid. Yield: $60 \%$. TLC (hexane/EtOAc 85:15): $\mathrm{R}_{\mathrm{f}}$ : 0.36. Mp: 107-109 ${ }^{\circ} \mathrm{C} .{ }^{1} \mathrm{H}-\mathrm{NMR}(300 \mathrm{MHz}$, $\left.\mathrm{CDCl}_{3}\right): \delta 8.44(\mathrm{br} \mathrm{s}, 1 \mathrm{H}, \mathrm{NH}), 8.13(\mathrm{~d}, J=9.1 \mathrm{~Hz}, 1 \mathrm{H}, \mathrm{ArH}), 7.18(\mathrm{~d}, J=8.2 \mathrm{~Hz}, 1 \mathrm{H}, \mathrm{ArH}), 6.96(\mathrm{~d}$, $J=2.2 \mathrm{~Hz}, 1 \mathrm{H}, \mathrm{ArH}), 6.60(\mathrm{dd}, J=9.1,2.2 \mathrm{~Hz}, 1 \mathrm{H}, \mathrm{ArH}), 6.53(\mathrm{~d}, J=2.4,1 \mathrm{H}, \mathrm{ArH}), 6.49(\mathrm{dd}, J=8.2$, $2.4 \mathrm{~Hz}, 1 \mathrm{H}, \mathrm{ArH}), 4.44\left(\mathrm{~d}, J=5.7 \mathrm{~Hz}, 2 \mathrm{H}, \mathrm{CH}_{2}\right), 3.89\left(\mathrm{~s}, 3 \mathrm{H}, \mathrm{CH}_{3}\right), 3.84\left(\mathrm{~s}, 3 \mathrm{H}, \mathrm{CH}_{3}\right) \mathrm{ppm} .{ }^{13} \mathrm{C}-\mathrm{NMR}$ $\left(75 \mathrm{MHz}, \mathrm{CDCl}_{3}\right): \delta 160.9,158.4,145.8,142.7,130.7,129.6,128.2,117.1,115.7,113.6,104.3,98.8,55.42$, $55.41,42.2 \mathrm{ppm}$.

5-Bromo- $N$-[(4-methoxyphenyl)methyl]-4-methyl-2-nitroaniline, 8

1,5-dibromo-2-methyl-4-nitrobenzene and $\mathrm{PMB}-\mathrm{NH}_{2}$ were reacted according to Procedure $\mathrm{B}$ to yield 8 as an orange solid. Yield: 95\%. TLC (hexane/EtOAc 9:1): $\mathrm{R}_{\mathrm{f}}: 0.28$. Mp: $115-116{ }^{\circ} \mathrm{C} .{ }^{1} \mathrm{H}-\mathrm{NMR}$ $\left(300 \mathrm{MHz}, \mathrm{CD}_{3} \mathrm{OD}\right): \delta 8.37(\mathrm{~s}, 1 \mathrm{H}, \mathrm{ArH}), 8.27(\mathrm{br} \mathrm{s}, 1 \mathrm{H}, \mathrm{NH}), 7.28(\mathrm{~d}, J=8.7 \mathrm{~Hz}, 2 \mathrm{H}, \mathrm{ArH}), 6.93(\mathrm{~d}$, $J=8.7 \mathrm{~Hz}, 2 \mathrm{H}, \mathrm{ArH}), 6.75(\mathrm{~s}, 1 \mathrm{H}, \mathrm{ArH}), 4.46\left(\mathrm{~d}, J=5.4 \mathrm{~Hz}, 2 \mathrm{H}, \mathrm{CH}_{2}\right), 3.84\left(\mathrm{~s}, 3 \mathrm{H}, \mathrm{CH}_{3}\right), 2.37(\mathrm{~s}, 3 \mathrm{H}$, $\mathrm{CH}_{3}$ ) ppm. ${ }^{13} \mathrm{C}-\mathrm{NMR}\left(75 \mathrm{MHz}, \mathrm{CD}_{3} \mathrm{OD}\right): \delta 8159.3,147.1,144.1,132.0,129.6,128.9,128.4,115.4,114.4$, $110.1,55.3,46.7,23.8 \mathrm{ppm}$.

\section{5-Chloro-N1-[(2,4-dimethoxyphenyl)methyl]benzene-1,2-diamine, 9}

Procedure C: $\mathrm{Zn}$ dust $(350 \mathrm{mg}, 5.36 \mathrm{mmol})$ and $\mathrm{NH}_{4} \mathrm{Cl}(46.6 \mathrm{mg}, 0.87 \mathrm{mmol})$ were added in a single portion to a stirred suspension of intermediate 7 (216 mg, 0.67 mmol) in $\mathrm{MeOH} / \mathrm{H}_{2} \mathrm{O}$ 9:1 $(10 \mathrm{~mL})$. The reaction was stirred at reflux for $3 \mathrm{~h}$. After completion, the mixture was filtered through celite, and the filtrate was evaporated under vacuum. The residue was diluted with $\mathrm{H}_{2} \mathrm{O}(6 \mathrm{~mL})$ and extracted with EtOAc $(3 \times 5 \mathrm{~mL})$. The collected organic layers were dried over $\mathrm{Na}_{2} \mathrm{SO}_{4}$, filtered, and concentrated in vacuo. The crude residue was purified by flash column chromatography (hexane/EtOAc from 7:3 to 6:4) to obtain the desired compound as a brown solid. Yield: 71\%. TLC (hexane/EtOAc 7:3): $\mathrm{R}_{\mathrm{f}}: 0.28$. Mp: $135-138{ }^{\circ} \mathrm{C} .{ }^{1} \mathrm{H}-\mathrm{NMR}\left(300 \mathrm{MHz}, \mathrm{CDCl}_{3}\right): \delta 7.21(\mathrm{~d}, J=8.2 \mathrm{~Hz}, 1 \mathrm{H}, \mathrm{ArH}), 6.71(\mathrm{~d}, J=2.0 \mathrm{~Hz}, 1 \mathrm{H}$, ArH), 6.65-6.62 (m, 2H, ArH), $6.52(\mathrm{~d}, J=2.4 \mathrm{~Hz}, 1 \mathrm{H}, \mathrm{ArH}), 6.48(\mathrm{dd}, J=8.2,2.4 \mathrm{~Hz}, 1 \mathrm{H}, \mathrm{ArH}), 4.22(\mathrm{~s}$, $\left.2 \mathrm{H}, \mathrm{CH}_{2}\right), 3.86\left(\mathrm{~s}, 3 \mathrm{H}, \mathrm{CH}_{3}\right), 3.83\left(\mathrm{~s}, 3 \mathrm{H}, \mathrm{CH}_{3}\right), 3.48\left(\mathrm{br} \mathrm{s}, 2 \mathrm{H}, \mathrm{NH}_{2}\right) \mathrm{ppm}$. 
5-Bromo-N1-[(4-methoxyphenyl)methyl]-4-methylbenzene-1,2-diamine, 10

The compound was obtained from 8 following Procedure $C$. The crude residue was purified by flash column chromatography (hexane/EtOAc from 8:2 to 7:3) to afford a yellow solid. Yield: 71\%. TLC (hexane/EtOAc 8:2): $\mathrm{R}_{\mathrm{f}}: 0.31$. Mp: $147-149{ }^{\circ} \mathrm{C} .{ }^{1} \mathrm{H}-\mathrm{NMR}\left(300 \mathrm{MHz}, \mathrm{CDCl}_{3}\right): \delta 7.32(\mathrm{~d}, J=8.8 \mathrm{~Hz}, 2 \mathrm{H}$, $\mathrm{ArH}), 6.92(\mathrm{~d}, J=8.8 \mathrm{~Hz}, 2 \mathrm{H}, \mathrm{ArH}), 6.91(\mathrm{~s}, 1 \mathrm{H}, \mathrm{ArH}), 6.56(\mathrm{~s}, 1 \mathrm{H}, \mathrm{ArH}), 4.22\left(\mathrm{~s}, 2 \mathrm{H}, \mathrm{CH}_{2}\right), 3.84(\mathrm{~s}, 3 \mathrm{H}$, $\left.\mathrm{CH}_{3}\right), 3.30$ (br s, $\left.2 \mathrm{H}, \mathrm{NH}_{2}\right), 2.30\left(\mathrm{~s}, 3 \mathrm{H}, \mathrm{CH}_{3}\right)$ ppm. ${ }^{13} \mathrm{C}-\mathrm{NMR}\left(75 \mathrm{MHz}, \mathrm{CDCl}_{3}\right): \delta 159.0,137.3,133.1$, 131.1, 129.2, 129.1, 119.9, 114.1, 113.9, 112.4, 55.3, 48.1, 22.3 ppm.

6-Chloro-1-[(2,4-dimethoxyphenyl)methyl]-1H,3H-2,1,3-benzothiadiazole-2,2-dioxide, 11

Intermediate 9 was reacted for $1.5 \mathrm{~h}$ following Procedure A. The crude residue was purified by flash column chromatography (hexane/EtOAc 6:4) to afford a brown oil. Yield: 55\%. TLC (hexane/EtOAc 6:4): $\mathrm{R}_{\mathrm{f}}: 0.21 .{ }^{1} \mathrm{H}-\mathrm{NMR}\left(300 \mathrm{MHz}, \mathrm{CDCl}_{3}\right): \delta 7.33(\mathrm{~d}, J=8.3 \mathrm{~Hz}, 1 \mathrm{H}, \mathrm{ArH}), 6.86(\mathrm{dd}, J=8.3,2.0 \mathrm{~Hz}, 1 \mathrm{H}$, $\mathrm{ArH}), 6.80-6.73(\mathrm{~m}, 2 \mathrm{H}, \mathrm{ArH}), 6.53-6.44(\mathrm{~m}, 2 \mathrm{H}, \mathrm{ArH}), 4.82\left(\mathrm{~s}, 2 \mathrm{H}, \mathrm{CH}_{2}\right), 3.91\left(\mathrm{~s}, 3 \mathrm{H}, \mathrm{CH}_{3}\right), 3.82(\mathrm{~s}, 3 \mathrm{H}$, $\left.\mathrm{CH}_{3}\right) \mathrm{ppm}$.

6-Bromo-1-[(4-methoxyphenyl)methyl]-5-methyl-1H,3H-2,1,3-benzothiadiazole-2,2-dioxide, 12

Intermediate 10 was reacted for $1.5 \mathrm{~h}$ following Procedure A. The purification was performed by flash column chromatography (hexane/EtOAc 6:4) to give the desired compound as a yellow oil. Yield: 56\%. TLC (hexane/EtOAc 6:4): $\mathrm{R}_{\mathrm{f}}: 0.27 .{ }^{1} \mathrm{H}-\mathrm{NMR}\left(300 \mathrm{MHz}, \mathrm{CDCl}_{3}\right): \delta 7.39$ (d, $\left.J=8.8 \mathrm{~Hz}, 2 \mathrm{H}, \mathrm{ArH}\right)$, $7.02(\mathrm{~s}, 1 \mathrm{H}, \mathrm{ArH}), 6.93(\mathrm{~d}, J=8.8 \mathrm{~Hz}, 2 \mathrm{H}, \mathrm{ArH}), 6.42(\mathrm{~s}, 1 \mathrm{H}, \mathrm{ArH}), 4.79\left(\mathrm{~s}, 2 \mathrm{H}, \mathrm{CH}_{2}\right), 3.83\left(\mathrm{~s}, 3 \mathrm{H}, \mathrm{CH}_{3}\right)$, $2.25\left(\mathrm{~s}, 3 \mathrm{H}, \mathrm{CH}_{3}\right) \mathrm{ppm} .{ }^{13} \mathrm{C}-\mathrm{NMR}\left(75 \mathrm{MHz}, \mathrm{CDCl}_{3}\right): \delta 159.6,132.6,130.7,128.9,126.0,125.6,115.8,115.4$, $114.4,110.9,55.3,46.1,23.0 \mathrm{ppm}$.

\section{5-Chloro-1H,3H-2,1,3-benzothiadiazole-2,2-dioxide, 1e}

Procedure D: Intermediate 11 (40 mg, $0.113 \mathrm{mmol})$ was dissolved in DCM (1 mL), and TFA (1 mL) was added dropwise. The reaction mixture was stirred for $45 \mathrm{~min}$ at $40^{\circ} \mathrm{C}$. After the evaporation of TFA under vacuum, $\mathrm{MeOH}$ was added and the white precipitate was filtered off. The filtrate was concentrated in vacuo and purified by flash column chromatography (hexane/EtOAc 6:4) to give product 1e as a pale pink solid. Yield: $82 \%$. TLC (hexane/EtOAc 6:4): $\mathrm{R}_{\mathrm{f}}: 0.48$. Mp: $183{ }^{\circ} \mathrm{C} .{ }^{1} \mathrm{H}-\mathrm{NMR}$ (300 MHz, CD $\left.{ }_{3} \mathrm{OD}\right): \delta 6.91(\mathrm{dd}, J=8.4,2.1 \mathrm{~Hz}, 1 \mathrm{H}, \mathrm{ArH}), 6.83(\mathrm{~d}, J=2.1 \mathrm{~Hz}, 1 \mathrm{H}, \mathrm{ArH}), 6.78(\mathrm{~d}, J=8.4 \mathrm{~Hz}$, $1 \mathrm{H}, \mathrm{ArH}) \mathrm{ppm} .{ }^{13} \mathrm{C}-\mathrm{NMR}\left(75 \mathrm{MHz}, \mathrm{CD}_{3} \mathrm{OD}\right): \delta 130.8,128.4,126.4,121.0,111.0,110.1 \mathrm{ppm}$. Anal. calcd (\%) for $\mathrm{C}_{6} \mathrm{H}_{5} \mathrm{ClN}_{2} \mathrm{O}_{2} \mathrm{~S}: \mathrm{C}, 35.22 ; \mathrm{H}, 2.46 ; \mathrm{N}, 13.69 ; \mathrm{S}, 15.67$; found: $\mathrm{C}, 34.98 ; \mathrm{H}, 2.49 ; \mathrm{N}, 13.42 ; \mathrm{S}, 15.48$.

\section{5-Bromo-6-methyl-1H,3H-2,1,3-benzothiadiazole-2,2-dioxide, 2a}

The product was obtained starting from intermediate 12 following Procedure D. The crude residue was purified by flash column chromatography (DCM/MeOH 95:5) to yield the desired compound as a white solid. Yield: 85\%. TLC (DCM/MeOH 95:5): $\mathrm{R}_{\mathrm{f}}: 0.19$. Mp: $185{ }^{\circ} \mathrm{C} .{ }^{1} \mathrm{H}-\mathrm{NMR}\left(300 \mathrm{MHz}, \mathrm{CD}_{3} \mathrm{OD}\right)$ : $\delta 6.99(\mathrm{~s}, 1 \mathrm{H}, \mathrm{ArH}), 6.77$ (s, $1 \mathrm{H}, \mathrm{ArH}), 2.32\left(\mathrm{~s}, 3 \mathrm{H}, \mathrm{CH}_{3}\right) \mathrm{ppm} .{ }^{13} \mathrm{C}-\mathrm{NMR}\left(75 \mathrm{MHz}, \mathrm{CD}_{3} \mathrm{OD}\right): \delta 130.5$, 129.5, 129.0, 115.2, 113.6, 112.0, 21.3 ppm. Anal. calcd (\%) for $\mathrm{C}_{7} \mathrm{H}_{7} \mathrm{BrN}_{2} \mathrm{O}_{2} \mathrm{~S}: \mathrm{C}, 31.95 ; \mathrm{H}, 2.68 ; \mathrm{N}, 10.65$; S, 12.19; found: C, 32.08; H, 2.75; N, 10.29; S, 12.31 .

\section{1,3-Bis[(4-methoxyphenyl)methyl]-5-nitro-2,1,3-benzothiadiazole-2,2-dioxide, 13}

Procedure E: To a stirred solution of $1 \mathbf{d}(140 \mathrm{mg}, 0.65 \mathrm{mmol})$ in dry DMF $(2 \mathrm{~mL})$, dried $\mathrm{K}_{2} \mathrm{CO}_{3}$ $(179.7 \mathrm{mg}, 1.3 \mathrm{mmol})$ and PMB-Br $(313.6 \mathrm{mg}, 1.56 \mathrm{mmol})$ were added. The mixture was stirred at $80{ }^{\circ} \mathrm{C}$ for $2 \mathrm{~h}$ and then cooled to room temperature, diluted with $\mathrm{H}_{2} \mathrm{O}(6 \mathrm{~mL})$, and extracted with EtOAc $(2 \times 5 \mathrm{~mL})$. The collected organic layers were dried over anhydrous $\mathrm{Na}_{2} \mathrm{SO}_{4}$, filtered, and evaporated in vacuo. The crude residue was purified by flash chromatography (hexane/EtOAc 8:2) to give intermediate 13 as a yellow solid. Yield: $90 \%$. TLC (hexane/EtOAc 8:2): $\mathrm{R}_{\mathrm{f}}: 0.28 . \mathrm{Mp}: 116^{\circ} \mathrm{C}$. ${ }^{1} \mathrm{H}-\mathrm{NMR}\left(300 \mathrm{MHz}, \mathrm{CDCl}_{3}\right): \delta 7.71(\mathrm{dd}, J=8.8,2.2 \mathrm{~Hz}, 1 \mathrm{H}, \mathrm{ArH}), 7.38-7.33(\mathrm{~m}, 3 \mathrm{H}, \mathrm{ArH}), 7.30(\mathrm{~d}$, 
$J=8.8 \mathrm{~Hz}, 2 \mathrm{H}, \mathrm{ArH}), 6.85(\mathrm{~d}, J=8.8 \mathrm{~Hz}, 2 \mathrm{H}, \mathrm{ArH}), 6.83(\mathrm{~d}, J=8.8 \mathrm{~Hz}, 2 \mathrm{H}, \mathrm{ArH}), 6.50(\mathrm{~d}, J=8.8 \mathrm{~Hz}$, $1 \mathrm{H}, \mathrm{ArH}), 4.86\left(\mathrm{~s}, 4 \mathrm{H}, \mathrm{CH}_{2}\right), 3.73\left(\mathrm{~s}, 3 \mathrm{H}, \mathrm{CH}_{3}\right), 3.72\left(\mathrm{~s}, 3 \mathrm{H}, \mathrm{CH}_{3}\right) \mathrm{ppm} .{ }^{13} \mathrm{C}-\mathrm{NMR}\left(75 \mathrm{MHz}, \mathrm{CDCl}_{3}\right): \delta$ $159.88,159.86,142.1$, 133.7, 129.3, 129.1, 128.7, 124.96, 124.93, 118.4, 114.59, 114.56, 107.3, 103.7, 55.3, $46.5,46.2 \mathrm{ppm}$.

5-Amino-1,3-bis[(4-methoxyphenyl)methyl]-2,1,3-benzothiadiazole-2,2-dioxide, 14

Intermediate 13 was reacted for $4 \mathrm{~h}$ following Procedure $\mathrm{C}$. The crude residue was purified by flash column chromatography (cyclohexane/EtOAc from 1:1 to 4:6) to give the desired product as a yellow oil. Yield: 46\%. TLC (cyclohexane/EtOAc 6:4): $\mathrm{R}_{\mathrm{f}}: 0.23 .{ }^{1} \mathrm{H}-\mathrm{NMR}\left(300 \mathrm{MHz}, \mathrm{CDCl}_{3}\right): \delta 7.32-7.25$ $(\mathrm{m}, 4 \mathrm{H}, \mathrm{ArH}), 6.84-6.77(\mathrm{~m}, 4 \mathrm{H}, \mathrm{ArH}), 6.25(\mathrm{~d}, J=8.3 \mathrm{~Hz}, 1 \mathrm{H}, \mathrm{ArH}), 6.01(\mathrm{dd}, J=8.3,2.3 \mathrm{~Hz}, 1 \mathrm{H}, \mathrm{ArH})$, $5.85(\mathrm{~d}, J=2.3 \mathrm{~Hz}, 1 \mathrm{H}, \mathrm{ArH}), 4.68\left(\mathrm{~s}, 2 \mathrm{H}, \mathrm{CH}_{2}\right), 4.67\left(\mathrm{~s}, 2 \mathrm{H}, \mathrm{CH}_{2}\right), 3.71\left(\mathrm{~s}, 6 \mathrm{H}, \mathrm{CH}_{3}\right), 3.31\left(\mathrm{br} \mathrm{s}, 2 \mathrm{H}, \mathrm{NH}_{2}\right)$ ppm. ${ }^{13} \mathrm{C}-\mathrm{NMR}\left(75 \mathrm{MHz}, \mathrm{CDCl}_{3}\right): \delta 159.40,159.39,141.7,130.8,129.0,128.8,127.0,126.7,121.9,114.3$, $114.2,110.2,107.5,97.3,55.29,55.28,47.2,46.1 \mathrm{ppm}$.

$\mathrm{N}$-\{1,3-Bis[(4-methoxyphenyl)methyl]-2,2-dioxo-2,1,3-benzothiadiazol-5-yl\}acetamide, 15

Intermediate $14(114.9 \mathrm{mg}, 0.27 \mathrm{mmol})$ was dissolved in acetone $(2 \mathrm{~mL})$, and the mixture was cooled to $0{ }^{\circ} \mathrm{C}$ in an ice bath. Acetic anhydride $(41.3 \mathrm{mg}, 0.41 \mathrm{mmol})$ was added dropwise, and the solution was stirred at room temperature for $2 \mathrm{~h}$. After completion, the solvent was removed in vacuo and the residue was diluted with $1 \mathrm{M} \mathrm{NaOH}$ and extracted with EtOAc $(2 \times 3 \mathrm{~mL})$. The collected organic layers were dried over anhydrous $\mathrm{Na}_{2} \mathrm{SO}_{4}$, filtered, and concentrated in vacuo. The crude residue was purified by flash column chromatography (cyclohexane/EtOAc from 5:5 to 4:6) to obtain intermediate 15 as a dark green solid. Yield: 98\%. TLC (cyclohexane/EtOAc 4:6): $\mathrm{R}_{\mathrm{f}}: 0.22 . \mathrm{Mp}: 153{ }^{\circ} \mathrm{C}$. ${ }^{1} \mathrm{H}-\mathrm{NMR}\left(300 \mathrm{MHz}, \mathrm{CDCl}_{3}\right): \delta 7.43-7.37(\mathrm{~m}, 5 \mathrm{H}, \mathrm{ArH}$ and NH$), 7.11(\mathrm{~d}, J=2.1 \mathrm{~Hz}, 1 \mathrm{H}, \mathrm{ArH}), 6.94-6.85$ $(\mathrm{m}, 4 \mathrm{H}, \mathrm{ArH}), 6.73(\mathrm{dd}, J=8.4,2.1 \mathrm{~Hz}, 1 \mathrm{H}, \mathrm{ArH}), 6.44(\mathrm{~d}, J=8.4 \mathrm{~Hz}, 1 \mathrm{H}, \mathrm{ArH}), 4.82\left(\mathrm{~s}, 2 \mathrm{H}, \mathrm{CH}_{2}\right), 4.81(\mathrm{~s}$, $\left.2 \mathrm{H}, \mathrm{CH}_{2}\right), 3.81\left(\mathrm{~s}, 3 \mathrm{H}, \mathrm{OCH}_{3}\right), 3.78\left(\mathrm{~s}, 3 \mathrm{H}, \mathrm{OCH}_{3}\right), 2.06\left(\mathrm{~s}, 3 \mathrm{H}, \mathrm{CH}_{3}\right) \mathrm{ppm} .{ }^{13} \mathrm{C}-\mathrm{NMR}\left(75 \mathrm{MHz}, \mathrm{CDCl}_{3}\right)$ : $\delta 168.4,159.49,159.47,132.4,129.5,129.2,129.0,126.4,126.3,125.7,114.3,112.8,108.7,101.8,55.29,55.25$, $46.4,46.1,24.3 \mathrm{ppm}$.

\section{N-(2,2-Dioxo-1H,3H-2,1,3-benzothiadiazol-5-yl)acetamide, 1 ff}

Intermediate 15 was reacted for $8 \mathrm{~h}$ at room temperature following Procedure $\mathrm{D}$. The crude residue was purified by flash column chromatography (DCM/MeOH from 95:5 to 9:1) to afford a white foam. Yield: 52\%. TLC (DCM/MeOH 85:15): $\mathrm{R}_{\mathrm{f}}: 0.37 .{ }^{1} \mathrm{H}-\mathrm{NMR}\left(300 \mathrm{MHz}, \mathrm{CD}_{3} \mathrm{OD}\right): \delta 7.14(\mathrm{~d}, J=2.1 \mathrm{~Hz}$, $1 \mathrm{H}, \mathrm{ArH}), 6.83(\mathrm{dd}, J=8.4,2.1 \mathrm{~Hz}, 1 \mathrm{H}, \mathrm{ArH}), 6.64(\mathrm{~d}, J=8.4 \mathrm{~Hz}, 1 \mathrm{H}, \mathrm{ArH}), 1.99\left(\mathrm{~s}, 3 \mathrm{H}, \mathrm{CH}_{3}\right) \mathrm{ppm}$. ${ }^{13} \mathrm{C}-\mathrm{NMR}\left(75 \mathrm{MHz}, \mathrm{CD}_{3} \mathrm{OD}\right): \delta 170.0,133.0,130.3,126.2,113.1,110.3,103.3,22.2 \mathrm{ppm}$. Anal. calcd (\%) for $\mathrm{C}_{8} \mathrm{H}_{9} \mathrm{~N}_{3} \mathrm{O}_{3} \mathrm{~S}: \mathrm{C}, 42.28 ; \mathrm{H}, 3.99 ; \mathrm{N}, 18.49 ; \mathrm{O}, 21.12 ; \mathrm{S}, 14.11$; found: $\mathrm{C}, 42.37 ; \mathrm{H}, 4.02 ; \mathrm{N}, 18.65 ; \mathrm{S}, 14.32$.

4-Bromo- $N$-[(4-methoxyphenyl)methyl]-2-nitroaniline, 16

A mixture of 2,5-dibromo-nitrobenzene (200 mg, $0.71 \mathrm{mmol})$ and $\mathrm{PMB}^{-\mathrm{NH}_{2}}(293 \mathrm{mg}, 2.14 \mathrm{mmol})$ was heated at $160{ }^{\circ} \mathrm{C}$ for $8 \mathrm{~h}$. After cooling, the reaction was diluted with $\mathrm{H}_{2} \mathrm{O}(4 \mathrm{~mL})$ and extracted with EtOAc $(2 \times 4 \mathrm{~mL})$. The collected organic layers were washed with $0.5 \mathrm{M} \mathrm{HCl}(1 \times 8 \mathrm{~mL})$ and then dried over anhydrous $\mathrm{Na}_{2} \mathrm{SO}_{4}$, filtered, and concentrated in vacuo. The crude residue was purified by flash chromatography (cyclohexane/EtOAc 8:2) to afford the desired compound as an orange solid. Yield: 95\%. TLC (cyclohexane/EtOAc 9:1): $\mathrm{R}_{\mathrm{f}}$ : 0.35. Mp: $12{ }^{\circ} \mathrm{C} .{ }^{1} \mathrm{H}-\mathrm{NMR}\left(300 \mathrm{MHz}, \mathrm{CDCl}_{3}\right): \delta 8.25$ (br s, $1 \mathrm{H}, \mathrm{NH}), 8.23(\mathrm{~d}, J=2.4 \mathrm{~Hz}, 1 \mathrm{H}, \mathrm{ArH}), 7.35(\mathrm{dd}, J=9.2,2.4 \mathrm{~Hz}, 1 \mathrm{H}, \mathrm{ArH}), 7.16(\mathrm{~d}, J=8.8 \mathrm{~Hz}, 2 \mathrm{H}$, $\operatorname{ArH}), 6.81(\mathrm{~d}, J=8.8 \mathrm{~Hz}, 2 \mathrm{H}, \mathrm{ArH}), 6.65(\mathrm{~d}, J=9.2 \mathrm{~Hz}, 1 \mathrm{H}, \mathrm{ArH}), 4.37\left(\mathrm{~d}, J=5.5 \mathrm{~Hz}, 2 \mathrm{H}, \mathrm{CH}_{2}\right), 3.72(\mathrm{~s}$, $\left.3 \mathrm{H}, \mathrm{CH}_{3}\right)$ ppm. ${ }^{13} \mathrm{C}-\mathrm{NMR}\left(75 \mathrm{MHz}, \mathrm{CDCl}_{3}\right): \delta 159.3,144.1,138.9,132.5,128.9,128.7,128.4,116.0,114.4$, $106.8,55.3,46.7 \mathrm{ppm}$. 
4-Bromo-N1-[(4-methoxyphenyl)methyl]benzene-1,2-diamine, 17

Compound 16 was reacted according to Procedure $C$; the resulting crude residue was purified by flash column chromatography (cyclohexane/EtOAc from 7.5:2.5 to 7:3) to afford the desired product as a pale yellow solid. Yield: $54 \%$. TLC (cyclohexane/EtOAc 7:3): $\mathrm{R}_{\mathrm{f}}: 0.36 . \mathrm{Mp}: 116{ }^{\circ} \mathrm{C} .{ }^{1} \mathrm{H}-\mathrm{NMR}$ $\left(300 \mathrm{MHz}, \mathrm{CDCl}_{3}\right): \delta 7.32(\mathrm{~d}, J=8.8 \mathrm{~Hz}, 2 \mathrm{H}, \mathrm{ArH}), 6.96-6.88(\mathrm{~m}, 3 \mathrm{H}, \mathrm{ArH}), 6.86(\mathrm{~d}, J=2.4 \mathrm{~Hz}, 1 \mathrm{H}, \mathrm{ArH})$, $6.55(\mathrm{~d}, J=8.4 \mathrm{~Hz}, 1 \mathrm{H}, \mathrm{ArH}), 4.23\left(\mathrm{~s}, 2 \mathrm{H}, \mathrm{CH}_{2}\right), 3.84\left(\mathrm{~s}, 3 \mathrm{H}, \mathrm{CH}_{3}\right), 3.57($ br s, $1 \mathrm{H}, \mathrm{NH}), 3.40(\mathrm{br} \mathrm{s}, 2 \mathrm{H}$, $\mathrm{NH}_{2}$ ) ppm. ${ }^{13} \mathrm{C}-\mathrm{NMR}\left(75 \mathrm{MHz}, \mathrm{CDCl}_{3}\right): \delta 159.0,136.6,135.8,131.0,129.0,123.0,118.9,114.1,113.3$, $110.7,55.3,48.1 \mathrm{ppm}$.

5-Bromo-1-[(4-methoxyphenyl)methyl]-3H-2,1,3-benzothiadiazole-2,2-dioxide, 18

Intermediate 17 was reacted for $2 \mathrm{~h}$ following Procedure A. The crude residue was purified by flash column chromatography (cyclohexane/EtOAc from 6:4 to 1:1), to afford compound 18 as a red solid. Yield: $60 \%$. TLC (cyclohexane/EtOAc 6:4): $\mathrm{R}_{\mathrm{f}}: 0.19$. Mp: $166{ }^{\circ} \mathrm{C} .{ }^{1} \mathrm{H}-\mathrm{NMR}\left(300 \mathrm{MHz}, \mathrm{CDCl}_{3}\right): \delta$ $7.26(\mathrm{~d}, J=8.8 \mathrm{~Hz}, 2 \mathrm{H}, \mathrm{ArH}), 6.87-6.82(\mathrm{~m}, 2 \mathrm{H}, \mathrm{ArH}), 6.80(\mathrm{~d}, J=8.8 \mathrm{~Hz}, 2 \mathrm{H}, \mathrm{ArH}), 6.28(\mathrm{~d}, J=8.4 \mathrm{~Hz}$, $1 \mathrm{H}, \mathrm{ArH}), 4.69\left(\mathrm{~s}, 2 \mathrm{H}, \mathrm{CH}_{2}\right), 3.70\left(\mathrm{~s}, 3 \mathrm{H}, \mathrm{CH}_{3}\right) \mathrm{ppm} .{ }^{13} \mathrm{C}-\mathrm{NMR}\left(75 \mathrm{MHz}, \mathrm{CDCl}_{3}\right): \delta 159.6,129.7,129.0$, $127.8,125.8,125.5,114.4,114.3,113.7,110.1,55.3,46.0 \mathrm{ppm}$.

\section{5-Bromo-1,3-bis[(4-methoxyphenyl)methyl]-2,1,3-benzothiadiazole-2,2-dioxide, 19}

The desired product was obtained starting from 18 following Procedure E. The crude residue was purified by flash column chromatography (cyclohexane/EtOAc 8:2) to afford a pale yellow solid. Yield: 98\%. TLC (cyclohexane/EtOAc 7:3): $\mathrm{R}_{\mathrm{f}}: 0.59$. Mp: $134{ }^{\circ} \mathrm{C} .{ }^{1} \mathrm{H}-\mathrm{NMR}\left(300 \mathrm{MHz}, \mathrm{CDCl}_{3}\right): \delta 7.48-7.36(\mathrm{~m}$, $4 \mathrm{H}, \mathrm{ArH}), 6.98-6.84(\mathrm{~m}, 5 \mathrm{H}, \mathrm{ArH}), 6.70(\mathrm{~d}, J=1.9 \mathrm{~Hz}, 1 \mathrm{H}, \mathrm{ArH}), 6.42(\mathrm{~d}, J=8.4 \mathrm{~Hz}, 1 \mathrm{H}, \mathrm{ArH}), 4.86(\mathrm{~s}$, $\left.4 \mathrm{H}, \mathrm{CH}_{2}\right), 3.84\left(\mathrm{~s}, 3 \mathrm{H}, \mathrm{CH}_{3}\right), 3.83\left(\mathrm{~s}, 3 \mathrm{H}, \mathrm{CH}_{3}\right)$ ppm. ${ }^{13} \mathrm{C}-\mathrm{NMR}\left(75 \mathrm{MHz}, \mathrm{CDCl}_{3}\right): \delta 159.7,159.6,130.2$, $129.0,128.1,125.9,125.8,124.1,114.5,114.4,113.8,111.5,109.7,55.3,46.3$ ppm.

Ethyl (2E)-3-\{1,3-bis[(4-methoxyphenyl)methyl]-2,2-dioxo-2,1,3-benzothiadiazol-5-yl\} prop-2-enoate, 20

To a solution of intermediate $19(200 \mathrm{mg}, 0.41 \mathrm{mmol})$ in DMF $(2.0 \mathrm{~mL})$, triethylamine $(0.28 \mathrm{~mL}$, $2.05 \mathrm{mmol})$, ethyl acrylate $(0.17 \mathrm{~mL}, 1.64 \mathrm{mmol})$, tri-o-tolylphosphine $(74.8 \mathrm{mg}, 0.25 \mathrm{mmol})$, and tris(dibenzylideneacetone)dipalladium $(0)(75.1 \mathrm{mg}, 0.08 \mathrm{mmol}$ ) were added, and the mixture was heated to $80{ }^{\circ} \mathrm{C}$ for $20 \mathrm{~h}$. The reaction was then cooled to ambient temperature, and DMF was evaporated. The residue was diluted with $\mathrm{H}_{2} \mathrm{O}(3 \mathrm{~mL})$ and extracted with EtOAc $(3 \times 3 \mathrm{~mL})$. The collected organic layers were dried over $\mathrm{Na}_{2} \mathrm{SO}_{4}$, filtered, concentrated in vacuo, and purified by flash column chromatography (cyclohexane/EtOAc 8:2) to afford the desired product as a yellow foam. Yield: 50\%. TLC (cyclohexane/EtOAc 7:3): $\mathrm{R}_{\mathrm{f}}: 0.31 .{ }^{1} \mathrm{H}-\mathrm{NMR}\left(300 \mathrm{MHz}, \mathrm{CDCl}_{3}\right): \delta 7.39$ (d, J=16.0 Hz, $1 \mathrm{H}, \mathrm{CH}), 7.35-7.30(\mathrm{~m}, 4 \mathrm{H}, \mathrm{ArH}), 6.90(\mathrm{dd}, J=8.2,1.6 \mathrm{~Hz}, 1 \mathrm{H}, \mathrm{ArH}), 6.87-6.80(\mathrm{~m}, 4 \mathrm{H}, \mathrm{ArH}), 6.62(\mathrm{~d}$, $J=1.6 \mathrm{~Hz}, 1 \mathrm{H}, \mathrm{ArH}), 6.46(\mathrm{~d}, J=8.2 \mathrm{~Hz}, 1 \mathrm{H}, \mathrm{ArH}), 6.04(\mathrm{~d}, J=16.0 \mathrm{~Hz}, 1 \mathrm{H}, \mathrm{CH}), 4.80\left(\mathrm{~s}, 2 \mathrm{H}, \mathrm{CH}_{2}\right)$, $4.79\left(\mathrm{~s}, 2 \mathrm{H}, \mathrm{CH}_{2}\right), 4.14\left(\mathrm{q}, J=7.1 \mathrm{~Hz}, 2 \mathrm{H}, \mathrm{OCH}_{2}\right) 3.74\left(\mathrm{~s}, 3 \mathrm{H}, \mathrm{CH}_{3}\right), 3.72\left(\mathrm{~s}, 3 \mathrm{H}, \mathrm{CH}_{3}\right), 1.23(\mathrm{t}, J=7.1 \mathrm{~Hz}$, $\left.3 \mathrm{H}, \mathrm{CH}_{3}\right) .{ }^{13} \mathrm{C}-\mathrm{NMR}\left(75 \mathrm{MHz}, \mathrm{CDCl}_{3}\right): \delta 167.0,159.63,159,62,144.1,130.7,129.5,128.99,128.95,128.2$, $125.95,125.93,122.8,116.5,114.5,114.4,108.4,106.9,60.5,55.3,46.3,46.2,14.3$ ppm.

(2E)-3-\{1,3-Bis[(4-methoxyphenyl)methyl]-2,2-dioxo-2,1,3-benzothiadiazol-5-yl\} prop-2-enoic acid, 21

To a solution of intermediate 20 (53.4 mg, $0.105 \mathrm{mmol})$ in $\mathrm{MeOH}(2 \mathrm{~mL}), 3 \mathrm{M} \mathrm{NaOH}(1 \mathrm{~mL})$ was added, and the mixture was stirred at $80^{\circ} \mathrm{C}$ for $3 \mathrm{~h}$. After cooling, $\mathrm{MeOH}$ was evaporated under vacuum and $2 \mathrm{M} \mathrm{HCl}(1.5 \mathrm{~mL})$ was added until $\mathrm{pH} 2$. Extraction with EtOAc $(3 \times 3 \mathrm{~mL})$ was carried out, and the collected organic layers were dried over $\mathrm{Na}_{2} \mathrm{SO}_{4}$, filtered, and evaporated in vacuo to afford the acid $\mathbf{2 1}$ as a pale yellow solid, which was used in the next step for further purification. Yield: quantitative. TLC (DCM/MeOH 95:5): $\mathrm{R}_{\mathrm{f}}: 0.26 . \mathrm{Mp}: 125-127^{\circ} \mathrm{C} .{ }^{1} \mathrm{H}-\mathrm{NMR}\left(300 \mathrm{MHz}, \mathrm{CDCl}_{3}\right): \delta 7.55$ $(\mathrm{d}, J=16 \mathrm{~Hz}, 1 \mathrm{H}, \mathrm{CH}), 7.47-7.34(\mathrm{~m}, 4 \mathrm{H}, \mathrm{ArH}), 7.00(\mathrm{dd}, J=8.1,1.6 \mathrm{~Hz}, 1 \mathrm{H}, \mathrm{ArH}), 6.97-6.84(\mathrm{~m}, 4 \mathrm{H}$, ArH), $6.70(\mathrm{~d}, J=1.6 \mathrm{~Hz}, 1 \mathrm{H}, \mathrm{ArH}), 6.54(\mathrm{~d}, J=8.1 \mathrm{~Hz}, 1 \mathrm{H}, \mathrm{ArH}), 6.11(\mathrm{~d}, J=16 \mathrm{~Hz}, 1 \mathrm{H}, \mathrm{CH}), 4.89$ 
(s, $\left.4 \mathrm{H}, \mathrm{CH}_{2}\right), 3.82\left(\mathrm{~s}, 3 \mathrm{H}, \mathrm{CH}_{3}\right), 3.80\left(\mathrm{~s}, 3 \mathrm{H}, \mathrm{CH}_{3}\right)$ ppm. ${ }^{13} \mathrm{C}-\mathrm{NMR}\left(75 \mathrm{MHz}, \mathrm{CDCl}_{3}\right): \delta 172.35,159.85$, $146.87,131.29,129.71,129.21,127.5,126.04,123.58,115.33,114.66,108.64,107.23,55.45,46.40$ ppm.

(2E)-3-\{1,3-Bis[(4-methoxyphenyl)methyl]-2,2-dioxo-2,1,3-benzothiadiazol-5-yl\}-N-(3-methylbutyl)prop2-enamide, 22

Procedure F: To a mixture of 21 ( $50.5 \mathrm{mg}, 0.105 \mathrm{mmol})$ in DCM (1 mL), isopentylamine (13.7 mg, 0.15 $\mathrm{mmol}$ ), $\mathrm{N}, \mathrm{N}$-diisopropylethylamine (DIPEA, $27.1 \mathrm{mg}, 0.21 \mathrm{mmol}$ ), and HATU ( $47.9 \mathrm{mg}, 0.126 \mathrm{mmol}$ ) were added. The reaction mixture was stirred at room temperature for $16 \mathrm{~h}$; after completion, the solvent was evaporated and the residue was diluted with $\mathrm{H}_{2} \mathrm{O}(3 \mathrm{~mL})$ and extracted with EtOAc $(3 \times 3 \mathrm{~mL})$. The organic layers were washed with $1 \mathrm{M} \mathrm{HCl}(1 \times 3 \mathrm{~mL})$ and then dried over $\mathrm{Na}_{2} \mathrm{SO}_{4}$, filtered, and concentrated in vacuo. Purification by flash column chromatography (DCM/MeOH 95:5) afforded compound 22 as a yellow oil. Yield: 62\%. TLC (DCM/EtOAc 9:1): $\mathrm{R}_{\mathrm{f}}: 0.55 .{ }^{1} \mathrm{H}-\mathrm{NMR}(300$ $\left.\mathrm{MHz}, \mathrm{CDCl}_{3}\right): \delta 7.45-7.36(\mathrm{~m}, 5 \mathrm{H}, \mathrm{ArH}), 7.00-6.87(\mathrm{~m}, 5 \mathrm{H}, \mathrm{ArH}, \mathrm{CH}), 6.67(\mathrm{~d}, J=1.6 \mathrm{~Hz}, 1 \mathrm{H}, \mathrm{ArH}), 6.53$ $(\mathrm{d}, J=8.2 \mathrm{~Hz}, 1 \mathrm{H}, \mathrm{ArH}), 6.09(\mathrm{~d}, J=15.5 \mathrm{~Hz}, 1 \mathrm{H}, \mathrm{CH}), 5.62(\mathrm{br} \mathrm{t}, J=5.7 \mathrm{~Hz}, 1 \mathrm{H}, \mathrm{NH}), 4.87\left(\mathrm{~s}, 4 \mathrm{H}, \mathrm{CH}_{2}\right)$, $3.82\left(\mathrm{~s}, 3 \mathrm{H}, \mathrm{OCH}_{3}\right), 3.81\left(\mathrm{~s}, 3 \mathrm{H}, \mathrm{OCH}_{3}\right), 3.40-3.35\left(\mathrm{~m}, 2 \mathrm{H}, \mathrm{CH}_{2}\right), 1.74-1.56(\mathrm{~m}, 1 \mathrm{H}, \mathrm{CH}), 1.47-1.41(\mathrm{~m}$, $\left.2 \mathrm{H}, \mathrm{CH}_{2}\right), 0.91\left(\mathrm{~d}, J=6.6 \mathrm{~Hz}, 6 \mathrm{H}, \mathrm{CH}_{3}\right)$ ppm. ${ }^{13} \mathrm{C}-\mathrm{NMR}\left(75 \mathrm{MHz}, \mathrm{CDCl}_{3}\right): \delta 165.8,159.58,159.57,140.3$, 130.1, 129.5, 128.99, 128.92, 128.7, 128.6, 126.1, 126.0, 122.0, 119.3, 114.43, 114.37, 114.0, 108.5, 107.1, 55.3, $46.23,46.17,38.6,38.0,25.9,22.4 \mathrm{ppm}$.

(2E)-3-\{1,3-Bis[(4-methoxyphenyl)methyl]-2,2-dioxo-2,1,3-benzothiadiazol-5-yl\}-N-phenylprop-2enamide, 23

To a stirred solution of 21 (50 mg, $0.104 \mathrm{mmol})$ in DCM $(2.5 \mathrm{~mL})$, aniline $(0.03 \mathrm{~mL}, 0.32 \mathrm{mmol})$, TBTU ( $46 \mathrm{mg}, 0.142 \mathrm{mmol}$ ), and $\mathrm{N}$-methylmorpholine (up to $\mathrm{pH} 7$ ) were added. The reaction mixture was stirred at room temperature for $24 \mathrm{~h}$. After completion, the product was extracted with DCM $(3 \times 3 \mathrm{~mL})$, and the organic layer was washed with $1 \mathrm{M} \mathrm{HCl}(1 \times 3 \mathrm{~mL})$ and then with a saturated solution of $\mathrm{NaHCO}_{3}(1 \times 3 \mathrm{~mL})$ and finally with brine $(1 \times 3 \mathrm{~mL})$. The organic phase was dried over anhydrous $\mathrm{Na}_{2} \mathrm{SO}_{4}$, filtered, and concentrated in vacuo. Purification by flash column chromatography (cyclohexane/EtOAc 7:3) yielded intermediate $\mathbf{2 3}$ as a white solid. Yield: 69\%. TLC (cyclohexane/EtOAc 6:4): $\mathrm{R}_{\mathrm{f}}: 0.47 . \mathrm{Mp}: 180-182{ }^{\circ} \mathrm{C} .{ }^{1} \mathrm{H}-\mathrm{NMR}\left(300 \mathrm{MHz}, \mathrm{CDCl}_{3}\right): \delta 7.57$ (br s, $\left.1 \mathrm{H}, \mathrm{NH}\right), 7.52(\mathrm{~d}, J=15.4 \mathrm{~Hz}$, $1 \mathrm{H}, \mathrm{CH}), 7.43-7.27(\mathrm{~m}, 8 \mathrm{H}, \mathrm{ArH}), 7.11(\mathrm{t}, J=7.4,1 \mathrm{H}, \mathrm{ArH}), 6.98(\mathrm{dd}, J=8.1,1.6 \mathrm{~Hz}, 1 \mathrm{H}, \mathrm{ArH}), 6.96-6.87$ $(\mathrm{m}, 4 \mathrm{H}, \mathrm{ArH}), 6.67(\mathrm{~d}, J=1.6 \mathrm{~Hz}, 1 \mathrm{H}, \mathrm{ArH}), 6.53(\mathrm{~d}, J=8.1 \mathrm{~Hz}, 1 \mathrm{H}, \mathrm{ArH}), 6.21(\mathrm{~d}, J=15.4 \mathrm{~Hz}, 1 \mathrm{H}, \mathrm{CH})$, $4.87\left(\mathrm{~s}, 4 \mathrm{H}, \mathrm{CH}_{2}\right), 3.81\left(\mathrm{~s}, 3 \mathrm{H}, \mathrm{CH}_{3}\right), 3.80\left(\mathrm{~s}, 3 \mathrm{H}, \mathrm{CH}_{3}\right) \mathrm{ppm}$.

\section{3-(2,2-Dioxo-1H,3H-2,1,3-benzothiadiazol-5-yl)-N-(3-methylbutyl)propanamide, $1 \mathbf{g}$}

Procedure G: Intermediate 22 (100 mg, $0.182 \mathrm{mmol})$ was dissolved in EtOH $(10 \mathrm{~mL})$, and the solution was degassed by bubbling Ar for $10 \mathrm{~min}$. $\mathrm{Pd} / \mathrm{C}(10 \% \mathrm{w} / \mathrm{w})$ was then added, and the mixture was stirred at room temperature under an $\mathrm{H}_{2}$ atmosphere $(3 \mathrm{~atm})$ for $48 \mathrm{~h}$. After completion, the reaction mixture was filtered through celite, and the filtrate was evaporated under vacuum. The crude residue was purified by flash column chromatography (DCM/MeOH 95:5 to 9:1) to obtain product $1 \mathrm{~g}$ as a pale brown oil. Yield: $3 \%$. TLC (DCM/MeOH 9:1): $\mathrm{R}_{\mathrm{f}}: 0.41 .{ }^{1} \mathrm{H}-\mathrm{NMR}\left(300 \mathrm{MHz}, \mathrm{CD}_{3} \mathrm{OD}\right): \delta$ 6.78-6.55 (m, 3H, ArH), $3.12\left(\mathrm{t}, J=7.5 \mathrm{~Hz}, 2 \mathrm{H}, \mathrm{CH}_{2}\right), 2.82\left(\mathrm{t}, J=7.5 \mathrm{~Hz}, 2 \mathrm{H}, \mathrm{CH}_{2}\right), 2.41(\mathrm{t}, J=7.5 \mathrm{~Hz}, 2 \mathrm{H}$, $\left.\mathrm{CH}_{2}\right), 1.55-1.37(\mathrm{~m}, 1 \mathrm{H}, \mathrm{CH}), 1.35-1.18\left(\mathrm{~m}, 2 \mathrm{H}, \mathrm{CH}_{2}\right), 0.86\left(\mathrm{~d}, J=6.6 \mathrm{~Hz}, 6 \mathrm{H}, \mathrm{CH}_{3}\right) \mathrm{ppm} .{ }^{13} \mathrm{C}-\mathrm{NMR}$ $\left(75 \mathrm{MHz}, \mathrm{CDCl}_{3}\right): \delta 173.5,134.6,130.2,128.2,121.2,110.2,37.8,37.1,31.4,25.2,21.3 \mathrm{ppm}$. Anal. calcd (\%) for $\mathrm{C}_{14} \mathrm{H}_{21} \mathrm{~N}_{3} \mathrm{O}_{3} \mathrm{~S}: \mathrm{C}, 54.00 ; \mathrm{H}, 6.80 ; \mathrm{N}, 13.49 ; \mathrm{S}, 10.30$; found: $\mathrm{C}, 54.08 ; \mathrm{H}, 6.95 ; \mathrm{N}, 13.27 ; \mathrm{S}, 10.41$.

\section{3-(2,2-Dioxo-1H,3H-2,1,3-benzothiadiazol-5-yl)-N-phenylpropanamide, $\mathbf{1 h}$}

The compound was obtained by reacting 23 at $50{ }^{\circ} \mathrm{C}$ for $5 \mathrm{~h}$ following Procedure G. The crude residue was purified by flash column chromatography (DCM/MeOH 9:1) to afford a white solid. Yield: 10\%. TLC (DCM/MeOH 9:1): $\mathrm{R}_{\mathrm{f}}: 0.40 . \mathrm{Mp}: 192-197^{\circ} \mathrm{C} .{ }^{1} \mathrm{H}-\mathrm{NMR}\left(300 \mathrm{MHz}, \mathrm{CD}_{3} \mathrm{OD}\right): \delta 7.51-7.45$ (m, $2 \mathrm{H}, \mathrm{ArH}), 7.33-7.22$ (m, 2H, ArH), 7.13-6.99 (m, 1H, ArH), 6.80 (dd, J = 8.1, 1.7 Hz, 1H, ArH), 6.76-6.70 
$(\mathrm{m}, 2 \mathrm{H}, \mathrm{ArH}) 2.93\left(\mathrm{t}, J=7.6 \mathrm{~Hz}, 2 \mathrm{H}, \mathrm{CH}_{2}\right), 2.61\left(\mathrm{t}, J=7.6 \mathrm{~Hz}, 2 \mathrm{H}, \mathrm{CH}_{2}\right)$ ppm. ${ }^{13} \mathrm{C}-\mathrm{NMR}(75 \mathrm{MHz}$, $\left.\mathrm{CD}_{3} \mathrm{OD}\right): \delta 172.1,138.3,134.8,130.1,128.3,128.1,123.8,121.3,120.0,110.3,38.7,31.2 \mathrm{ppm}$. Anal. calcd (\%) for $\mathrm{C}_{15} \mathrm{H}_{15} \mathrm{~N}_{3} \mathrm{O}_{3} \mathrm{~S}: \mathrm{C}, 56.77 ; \mathrm{H}, 4.76 ; \mathrm{N}, 13.24 ; \mathrm{S}, 10.10$; found: $\mathrm{C}, 56.89 ; \mathrm{H}, 4.81 ; \mathrm{N}, 13.16 ; \mathrm{S}, 10.14$.

1,3-Bis[(4-methoxyphenyl)methyl]-5-phenyl-2,1,3-benzothiadiazole-2,2-dioxide, 24

A flask was charged with $19(70 \mathrm{mg}, 0.14 \mathrm{mmol}), \mathrm{Na}_{2} \mathrm{CO}_{3}(30 \mathrm{mg}, 0.28 \mathrm{mmol})$, phenylboronic acid (18 mg, $0.15 \mathrm{mmol}$ ), and tetrakis(triphenylphosphine)palladium(0) (32 mg, $0.028 \mathrm{mmol}$ ) under an Ar atmosphere. Then, 1,4-dioxane $(3 \mathrm{~mL})$ and a drop of $\mathrm{H}_{2} \mathrm{O}$ were added. The resulting mixture was heated to reflux for $5 \mathrm{~h}$. After completion, the reaction was cooled to room temperature, $\mathrm{H}_{2} \mathrm{O}$ was added $(3 \mathrm{~mL})$, and the mixture was extracted with EtOAc $(3 \times 2 \mathrm{~mL})$. The collected organic layers were dried over $\mathrm{Na}_{2} \mathrm{SO}_{4}$, filtered, and evaporated in vacuo. The residue was purified by flash column chromatography (cyclohexane/EtOAc 7:3) to afford the desired product as a pale-yellow oil. Yield: $68 \%$. TLC (cyclohexane/EtOAc 7:3): $\mathrm{R}_{\mathrm{f}}: 0.50 .{ }^{1} \mathrm{H}-\mathrm{NMR}\left(300 \mathrm{MHz}, \mathrm{CDCl}_{3}\right): \delta 7.38-7.32(\mathrm{~m}, 4 \mathrm{H}, \mathrm{ArH})$, 7.30-7.23 (m, 4H, ArH, partially hidden by solvent peak), 7.22-7.17 (m, 1H, ArH), 6.93 (dd, J = 8.1, $1.8 \mathrm{~Hz}, 1 \mathrm{H}, \mathrm{ArH}), 6.87-6.80(\mathrm{~m}, 4 \mathrm{H}, \mathrm{ArH}), 6.70(\mathrm{~d}, J=1.8 \mathrm{~Hz}, 1 \mathrm{H}, \mathrm{ArH}), 6.52(\mathrm{~d}, J=8.1 \mathrm{~Hz}, 1 \mathrm{H}, \mathrm{ArH})$, $4.83\left(\mathrm{~s}, 2 \mathrm{H}, \mathrm{CH}_{2}\right), 4.80\left(\mathrm{~s}, 2 \mathrm{H}, \mathrm{CH}_{2}\right), 3.72\left(\mathrm{~s}, 3 \mathrm{H}, \mathrm{CH}_{3}\right), 3.71\left(\mathrm{~s}, 3 \mathrm{H}, \mathrm{CH}_{3}\right)$ ppm. ${ }^{13} \mathrm{C}-\mathrm{NMR}(75 \mathrm{MHz}$, $\left.\mathrm{CDCl}_{3}\right): \delta 159.5,140.7,135.2,129.7,129.04,129.02,128.97,128.8,128.6,127.1,126.8,126.4,120.4,114.37$, $114.35,114.31,108.8,107.4,55.3,46.33,46.29$ ppm.

5-Phenyl-1H,3H-2,1,3-benzothiadiazole-2,2-dioxide, $1 \mathbf{i}$

Intermediate $\mathbf{2 4}$ was reacted for $3 \mathrm{~h}$ at room temperature following Procedure $\mathrm{D}$. The crude residue was purified by flash column chromatography (cyclohexane/EtOAc 6:4) to afford a white solid. Yield: 20\%. TLC (cyclohexane/EtOAc 6:4): $\mathrm{R}_{\mathrm{f}}: 0.42 . \mathrm{Mp}: 180-185^{\circ} \mathrm{C} .{ }^{1} \mathrm{H}-\mathrm{NMR}\left(300 \mathrm{MHz}, \mathrm{CD}_{3} \mathrm{OD}\right.$ ): $87.47-7.38$ (m, 2H, ArH), 7.33-7.26 (m, 2H, ArH), 7.24-7.14 (m, 1H, ArH), $7.07(\mathrm{dd}, J=8.1,1.8 \mathrm{~Hz}, 1 \mathrm{H}, \mathrm{ArH}), 6.96$ $(\mathrm{d}, J=1.8 \mathrm{~Hz}, 1 \mathrm{H}, \mathrm{ArH}), 6.78(\mathrm{~d}, J=8.1 \mathrm{~Hz}, 1 \mathrm{H}, \mathrm{ArH}) \mathrm{ppm}$. Anal. calcd (\%) for $\mathrm{C}_{12} \mathrm{H}_{10} \mathrm{~N}_{2} \mathrm{O}_{2} \mathrm{~S}: \mathrm{C}, 58.52$; $\mathrm{H}, 4.09 ; \mathrm{N}, 11.37 ; \mathrm{S}, 13.02$; found: $\mathrm{C}, 58.48 ; \mathrm{H}, 4.11 ; \mathrm{N}, 11.26 ; \mathrm{S}, 13.18$.

\section{1,3-Dibenzyl-2,1,3-benzothiadiazole-2,2-dioxide, 3}

The compound was obtained starting from 1a and benzyl bromide following Procedure E. The crude residue was purified by flash column chromatography (hexane/EtOAc 9:1) to afford the desired product as a white solid. Yield: $90 \%$. TLC (hexane/EtOAc 7:3): $\mathrm{R}_{\mathrm{f}}: 0.81 . \mathrm{Mp}: 134{ }^{\circ} \mathrm{C} .{ }^{1} \mathrm{H}-\mathrm{NMR}$ (300 MHz, $\left.\mathrm{CDCl}_{3}\right): \delta 7.56-7.48(\mathrm{~m}, 4 \mathrm{H}, \mathrm{ArH}), 7.45-7.39(\mathrm{~m}, 4 \mathrm{H}, \mathrm{ArH}), 7.38-7.32(\mathrm{~m}, 2 \mathrm{H}, \mathrm{ArH}), 6.86-6.81$ (m, 2H, ArH), 6.59-6.54 (m, 2H, ArH), 4.96 (s, 4H, $\left.\mathrm{CH}_{2}\right)$ ppm. ${ }^{13} \mathrm{C}-\mathrm{NMR}\left(75 \mathrm{MHz}, \mathrm{CDCl}_{3}\right): \delta 134.6$, $129.3,128.9,128.1,127.5,121.6,108.5,46.7$ ppm. Anal. calcd (\%) for $\mathrm{C}_{20} \mathrm{H}_{18} \mathrm{~N}_{2} \mathrm{O}_{2} \mathrm{~S}: \mathrm{C}, 68.55 ; \mathrm{H}, 5.18 ; \mathrm{N}$, 7.99; S, 9.15; found: C, 68.63; H, 5.17; N, 8.13; S, 9.17.

\section{1,3,5-Trimethyl-2,1,3-benzothiadiazole-2,2-dioxide, 2b}

In a flame-dried flask, $\mathbf{1 b}(50 \mathrm{mg}, 0.27 \mathrm{mmol})$ was solubilized in dry DMF under an Ar atmosphere; oven-dried $\mathrm{K}_{2} \mathrm{CO}_{3}(111.9 \mathrm{mg}, 0.81 \mathrm{mmol})$ was then added, and the mixture was stirred for $30 \mathrm{~min}$. After cooling to $0{ }^{\circ} \mathrm{C}$ on an ice bath, $\mathrm{CH}_{3} \mathrm{I}(0.050 \mathrm{~mL}, 0.81 \mathrm{mmol})$ was added dropwise, and the reaction was heated at $80^{\circ} \mathrm{C}$ for $2 \mathrm{~h}$. After completion, DMF was removed under reduced pressure and the remaining mixture was diluted with $1 \mathrm{M} \mathrm{HCl}(3 \mathrm{~mL})$, and then the product was extracted with EtOAc $(3 \times 3 \mathrm{~mL})$. The organic fractions were combined, dried over anhydrous $\mathrm{Na}_{2} \mathrm{SO}_{4}$, filtered, and evaporated under vacuum. The crude residue was purified by flash column chromatography (hexane/EtOAc 8:2) to afford product $\mathbf{2 b}$ as a white foam. Yield: $87 \%$. TLC (hexane/EtOAc 6:4): $\mathrm{R}_{\mathrm{f}}$ : 0.78. ${ }^{1} \mathrm{H}-\mathrm{NMR}\left(300 \mathrm{MHz}, \mathrm{CDCl}_{3}\right): \delta 6.81(\mathrm{dd}, J=8.0,1.5 \mathrm{~Hz}, 1 \mathrm{H}, \mathrm{ArH}), 6.64(\mathrm{~d}, J=8.0 \mathrm{~Hz}, 1 \mathrm{H}, \mathrm{ArH})$, $6.58(\mathrm{~d}, J=1.5 \mathrm{~Hz}, 1 \mathrm{H}, \mathrm{ArH}), 3.28\left(\mathrm{~s}, 3 \mathrm{H}, \mathrm{NCH}_{3}\right), 3.27\left(\mathrm{~s}, 3 \mathrm{H}, \mathrm{NCH}_{3}\right), 2.36\left(\mathrm{~s}, 3 \mathrm{H}, \mathrm{CH}_{3}\right) \mathrm{ppm} .{ }^{13} \mathrm{C}-\mathrm{NMR}$ $\left(75 \mathrm{MHz}, \mathrm{CDCl}_{3}\right): \delta 131.7,130.4,128.2,122.0,108.7,107.7,28.2,27.9,21.4 \mathrm{ppm}$. Anal. calcd (\%) for $\mathrm{C}_{9} \mathrm{H}_{12} \mathrm{~N}_{2} \mathrm{O}_{2} \mathrm{~S}: \mathrm{C}, 50.92 ; \mathrm{H}, 5.70 ; \mathrm{N}, 13.20 ; \mathrm{S}, 15.11$; found: $\mathrm{C}, 50.78 ; \mathrm{H}, 5.63 ; \mathrm{N}, 13.28 ; \mathrm{S}, 15.17$. 
N-[(2,4-Dimethoxyphenyl)methyl]-2-nitroaniline, 25

In a two-neck flask, a solution of 1-chloro-2-nitrobenzene $(200 \mathrm{mg}, 1.27 \mathrm{mmol})$ and DMB-NH $(637 \mathrm{mg}, 3.8 \mathrm{mmol})$ in $\mathrm{EtOH}$ was heated overnight at $100^{\circ} \mathrm{C}$. After completion, $\mathrm{EtOH}$ was evaporated under vacuum, and the residue was dissolved in EtOAc and washed with $1 \mathrm{M} \mathrm{HCl}(1 \times 3 \mathrm{~mL})$. The organic layer was dried over anhydrous $\mathrm{Na}_{2} \mathrm{SO}_{4}$, filtered, and concentrated in vacuo. The crude residue was purified by flash column chromatography (hexane/EtOAc 8:2) to give the desired compound as an orange solid. Yield: $80 \%$. TLC (hexane/EtOAc 8:2): $\mathrm{R}_{\mathrm{f}}: 0.32$. Mp: $85-87^{\circ} \mathrm{C}$. ${ }^{1} \mathrm{H}-\mathrm{NMR}(300 \mathrm{MHz}$, $\left.\mathrm{CDCl}_{3}\right): \delta 8.43(\mathrm{br} \mathrm{s}, 1 \mathrm{H}, \mathrm{NH}), 8.20(\mathrm{dd}, J=8.7,1.7 \mathrm{~Hz}, 1 \mathrm{H}, \mathrm{ArH}), 7.43-7.39(\mathrm{~m}, 1 \mathrm{H}, \mathrm{ArH}), 7.17(\mathrm{~d}$, $J=8.4 \mathrm{~Hz}, 1 \mathrm{H}, \mathrm{ArH}), 6.91(\mathrm{dd}, J=8.7,1.7 \mathrm{~Hz}, 1 \mathrm{H}, \mathrm{ArH}), 6.67-6.62(\mathrm{~m}, 1 \mathrm{H}, \mathrm{ArH}), 6.52(\mathrm{~d}, J=2.4,1 \mathrm{H}$, ArH), $6.46(\mathrm{dd}, J=8.4,2.4 \mathrm{~Hz}, 1 \mathrm{H}, \mathrm{ArH}), 4.48\left(\mathrm{~d}, J=5.6 \mathrm{~Hz}, 2 \mathrm{H}, \mathrm{CH}_{2}\right), 3.88\left(\mathrm{~s}, 3 \mathrm{H}, \mathrm{CH}_{3}\right), 3.83(\mathrm{~s}, 3 \mathrm{H}$, $\left.\mathrm{CH}_{3}\right)$ ppm.

N1-[(2,4-Dimethoxyphenyl)methyl]benzene-1,2-diamine, 26

Intermediate 25 was reacted for $1 \mathrm{~h}$ at reflux following Procedure $\mathrm{C}$. The crude residue was purified by flash column chromatography (cyclohexane/EtOAc from 7:3 to 6:4) to afford a yellow solid. Yield: 73\%. TLC (cyclohexane/EtOAc 6:4): $\mathrm{R}_{\mathrm{f}}$ : 0.37. Mp: 107-112 ${ }^{\circ} \mathrm{C} .{ }^{1} \mathrm{H}-\mathrm{NMR}\left(300 \mathrm{MHz}, \mathrm{CDCl}_{3}\right.$ ): $\delta$ $7.27(\mathrm{~d}, J=8.2 \mathrm{~Hz}, 1 \mathrm{H}, \mathrm{ArH}), 6.92-6.82(\mathrm{~m}, 1 \mathrm{H}, \mathrm{ArH}), 6.78(\mathrm{~d}, J=8.4 \mathrm{~Hz}, 1 \mathrm{H}, \mathrm{ArH}), 6.77-6.73(\mathrm{~m}, 2 \mathrm{H}$, ArH), $6.56(\mathrm{~d}, J=2.4 \mathrm{~Hz}, 1 \mathrm{H}, \mathrm{ArH}), 6.51(\mathrm{dd}, J=8.2,2.4 \mathrm{~Hz}, 1 \mathrm{H}, \mathrm{ArH}), 4.30\left(\mathrm{~s}, 2 \mathrm{H}, \mathrm{CH}_{2}\right), 3.88(\mathrm{~s}, 3 \mathrm{H}$, $\left.\mathrm{CH}_{3}\right), 3.86\left(\mathrm{~s}, 3 \mathrm{H}, \mathrm{CH}_{3}\right), 3.52$ (br s, $\left.2 \mathrm{H}, \mathrm{NH}_{2}\right)$ ppm. ${ }^{13} \mathrm{C}-\mathrm{NMR}\left(75 \mathrm{MHz}, \mathrm{CDCl}_{3}\right): \delta 160.3,158.6,137.9$, $134.8,130.0,120.5,120.0,118.8,116.3,112.7,104.1,98.7,55.42,55.40,43.7 \mathrm{ppm}$.

1-[(2,4-Dimethoxyphenyl)methyl]-3H-2,1,3-benzothiadiazole-2,2-dioxide, 27

The product was obtained by reacting 26 for $2 \mathrm{~h}$ at $160{ }^{\circ} \mathrm{C}$ following Procedure A. The crude residue was purified by flash column chromatography (cyclohexane/EtOAc 6:4) to give the desired compound as a sticky yellow solid. Yield: $78 \%$. TLC (cyclohexane/EtOAc 1:1): $\mathrm{R}_{\mathrm{f}}: 0.31 .{ }^{1} \mathrm{H}-\mathrm{NMR}$ $\left(300 \mathrm{MHz}, \mathrm{CDCl}_{3}\right): \delta 7.33(\mathrm{~d}, J=8.4 \mathrm{~Hz}, 1 \mathrm{H}, \mathrm{ArH}), 7.03-6.84(\mathrm{~m}, 3 \mathrm{H}, \mathrm{ArH}), 6.72(\mathrm{dd}, J=7.3,1.1 \mathrm{~Hz}, 1 \mathrm{H}$, $\mathrm{ArH}), 6.52(\mathrm{~d}, J=2.4 \mathrm{~Hz}, 1 \mathrm{H}, \mathrm{ArH}), 6.48(\mathrm{dd}, J=8.4,2.4 \mathrm{~Hz}, 1 \mathrm{H}, \mathrm{ArH}), 4.86\left(\mathrm{~s}, 2 \mathrm{H}, \mathrm{CH}_{2}\right), 3.90(\mathrm{~s}, 3 \mathrm{H}$, $\left.\mathrm{CH}_{3}\right), 3.82\left(\mathrm{~s}, 3 \mathrm{H}, \mathrm{CH}_{3}\right) \mathrm{ppm}$.

Ethyl 2-\{3-[(2,4-dimethoxyphenyl)methyl]-2,2-dioxo-2,1,3-benzothiadiazol-1-yl\}acetate, 28

Intermediate 27 (100 mg, $0.31 \mathrm{mmol}), \mathrm{K}_{2} \mathrm{CO}_{3}(55.74 \mathrm{mg}, 0.403 \mathrm{mmol})$, and ethyl bromoacetate $(62.8 \mathrm{mg}, 0.38 \mathrm{mmol})$ were reacted according to Procedure E. The crude residue was purified by flash column chromatography (hexane/EtOAc 7:3) to afford the desired compound as a yellow solid. Yield: 90\%. TLC (hexane/EtOAc 6:4): $\mathrm{R}_{\mathrm{f}}: 0.52 . \mathrm{Mp}: 128-132{ }^{\circ} \mathrm{C} .{ }^{1} \mathrm{H}-\mathrm{NMR}\left(300 \mathrm{MHz}, \mathrm{CDCl}_{3}\right): \delta 7.34(\mathrm{~d}$, $J=8.4 \mathrm{~Hz}, 1 \mathrm{H}, \mathrm{ArH}), 6.97-6.90(\mathrm{~m}, 2 \mathrm{H}, \mathrm{ArH}), 6.75-6.67(\mathrm{~m}, 2 \mathrm{H}, \mathrm{ArH}), 6.51(\mathrm{~d}, J=2.4 \mathrm{~Hz}, 1 \mathrm{H}, \mathrm{ArH})$, $6.48(\mathrm{dd}, J=8.4,2.4 \mathrm{~Hz}, 1 \mathrm{H}, \mathrm{ArH}), 4.90\left(\mathrm{~s}, 2 \mathrm{H}, \mathrm{CH}_{2}\right), 4.47\left(\mathrm{~s}, 2 \mathrm{H}, \mathrm{CH}_{2}\right), 4.29\left(\mathrm{q}, J=7.1 \mathrm{~Hz}, 2 \mathrm{H}, \mathrm{OCH}_{2}\right)$, $3.90\left(\mathrm{~s}, 3 \mathrm{H}, \mathrm{OCH}_{3}\right), 3.82\left(\mathrm{~s}, 3 \mathrm{H}, \mathrm{OCH}_{3}\right), 1.30\left(\mathrm{t}, J=7.1 \mathrm{~Hz}, 3 \mathrm{H}, \mathrm{CH}_{3}\right) \mathrm{ppm}$.

2-\{3-[(2,4-Dimethoxyphenyl)methyl]-2,2-dioxo-2,1,3-benzothiadiazol-1-yl\} acetic acid, 29

To a solution of intermediate $28(63 \mathrm{mg}, 0.16 \mathrm{mmol})$ in $\mathrm{MeOH}(2 \mathrm{~mL}), 2 \%$ aqueous $\mathrm{K}_{2} \mathrm{CO}_{3}(1 \mathrm{~mL})$ was added, and the mixture was stirred at $50{ }^{\circ} \mathrm{C}$ for $2 \mathrm{~h}$. After cooling, $\mathrm{MeOH}$ was evaporated under vacuum, and $2 \mathrm{M} \mathrm{HCl}(1.5 \mathrm{~mL})$ was added until it reached $\mathrm{pH} 4$. Extraction with EtOAc $(3 \times 3 \mathrm{~mL})$ was carried out, and the collected organic layers were dried over anhydrous $\mathrm{Na}_{2} \mathrm{SO}_{4}$, filtered, and evaporated in vacuo to obtain the acid 29 as a yellow oil, which was used in the next step without any further purification. Yield: quantitative. TLC (DCM/MeOH 9:1): $\mathrm{R}_{\mathrm{f}}: 0.10 .{ }^{1} \mathrm{H}-\mathrm{NMR}\left(300 \mathrm{MHz}, \mathrm{CDCl}_{3}\right)$ : $\delta 9.91$ (br s, 1H, COOH), 7.32 (d, J = 8.4 Hz, 1H, ArH), 6.99-6.91 (m, 2H, ArH), 6.79-6.68 (m, 2H, ArH), $6.51(\mathrm{~d}, J=2.4 \mathrm{~Hz}, 1 \mathrm{H}, \mathrm{ArH}), 6.47(\mathrm{dd}, J=8.4,2.4 \mathrm{~Hz}, 1 \mathrm{H}, \mathrm{ArH}), 4.90\left(\mathrm{~s}, 2 \mathrm{H}, \mathrm{CH}_{2}\right), 4.52\left(\mathrm{~s}, 2 \mathrm{H}, \mathrm{CH}_{2}\right)$, $3.89\left(\mathrm{~s}, 3 \mathrm{H}, \mathrm{CH}_{3}\right), 3.81\left(\mathrm{~s}, 3 \mathrm{H}, \mathrm{CH}_{3}\right) \mathrm{ppm}$. 
2-\{3-[(2,4-Dimethoxyphenyl)methyl]-2,2-dioxo-2,1,3-benzothiadiazol-1-yl\}-N-phenethylacetamide, 30

Intermediate 29 and 2-phenylethanamine were reacted for $24 \mathrm{~h}$ following Procedure F. The crude residue was purified by flash column chromatography (hexane/EtOAc 6:4) to afford the desired compound as a yellow oil. Yield: 47\%. TLC (DCM/MeOH 95:5): $\mathrm{R}_{\mathrm{f}}: 0.83 .{ }^{1} \mathrm{H}-\mathrm{NMR}\left(300 \mathrm{MHz}, \mathrm{CDCl}_{3}\right)$ : $\delta 7.30(\mathrm{~d}, J=8.4 \mathrm{~Hz}, 1 \mathrm{H}, \mathrm{ArH}), 7.20-7.16(\mathrm{~m}, 3 \mathrm{H}, \mathrm{ArH}), 7.10-7.03(\mathrm{~m}, 2 \mathrm{H}, \mathrm{ArH}), 7.01-6.96(\mathrm{~m}, 2 \mathrm{H}, \mathrm{ArH})$, 6.85-6.78 (m, 1H, ArH), 6.70-6.64 (m, 1H, ArH), $6.63(\mathrm{br} \mathrm{t}, J=5.8 \mathrm{~Hz}, 1 \mathrm{H}, \mathrm{NH}), 6.53(\mathrm{~d}, J=2.4 \mathrm{~Hz}, 1 \mathrm{H}$, $\mathrm{ArH}), 6.50(\mathrm{dd}, J=8.4,2.4 \mathrm{~Hz}, 1 \mathrm{H}, \mathrm{ArH}), 4.88\left(\mathrm{~s}, 2 \mathrm{H}, \mathrm{CH}_{2}\right), 4.34\left(\mathrm{~s}, 2 \mathrm{H}, \mathrm{CH}_{2}\right), 3.92\left(\mathrm{~s}, 3 \mathrm{H}, \mathrm{CH}_{3}\right), 3.83(\mathrm{~s}$, $\left.3 \mathrm{H}, \mathrm{CH}_{3}\right), 3.56\left(\mathrm{td}, J=7.0,5.8 \mathrm{~Hz}, 2 \mathrm{H}, \mathrm{NHCH}_{2}\right), 2.78\left(\mathrm{t}, J=7.0 \mathrm{~Hz}, 2 \mathrm{H}, \mathrm{CH}_{2} \mathrm{CH}_{2}\right) \mathrm{ppm}$.

\section{2-(2,2-Dioxo-3H-2,1,3-benzothiadiazol-1-yl)- $N$-(2-phenylethyl)acetamide, 4}

Intermediate 30 was reacted according to Procedure D. The crude residue was purified by flash column chromatography (DCM/MeOH 95:5) to give the product as a white solid. Yield: $88 \%$. TLC (DCM/MeOH 9:1): $\mathrm{R}_{\mathrm{f}}: 0.41 . \mathrm{Mp}: 172{ }^{\circ} \mathrm{C} .{ }^{1} \mathrm{H}-\mathrm{NMR}\left(300 \mathrm{MHz}, \mathrm{CD}_{3} \mathrm{OD}\right): \delta 8.06(\mathrm{t}, J=5.9 \mathrm{~Hz}, 1 \mathrm{H}$, $\mathrm{NH}), 7.29-7.23(\mathrm{~m}, 2 \mathrm{H}, \mathrm{ArH}), 7.22-7.16(\mathrm{~m}, 3 \mathrm{H}, \mathrm{ArH}), 7.00-6.94(\mathrm{~m}, 2 \mathrm{H}, \mathrm{ArH}), 6.92-6.84(\mathrm{~m}, 1 \mathrm{H}, \mathrm{ArH})$, 6.70-6.58 (m, 1H, ArH), $4.27\left(\mathrm{~s}, 2 \mathrm{H}, \mathrm{CH}_{2}\right), 3.49\left(\mathrm{td}, J=7.2,5.9 \mathrm{~Hz}, 2 \mathrm{H}, \mathrm{NHCH}_{2}\right), 2.81(\mathrm{t}, J=7.2 \mathrm{~Hz}, 2 \mathrm{H}$, $\mathrm{CH}_{2} \mathrm{CH}_{2}$ ) ppm. ${ }^{13} \mathrm{C}-\mathrm{NMR}\left(75 \mathrm{MHz}, \mathrm{CD}_{3} \mathrm{OD}\right): \delta 167.6,138.8,131.3,128.5,128.1,126.0,121.9,121.7$, 110.5, 108.2, 44.2, 40.6, 35.0 ppm. Anal. calcd (\%) for $\mathrm{C}_{16} \mathrm{H}_{17} \mathrm{~N}_{3} \mathrm{O}_{3} \mathrm{~S}: \mathrm{C}, 57.99 ; \mathrm{H}, 5.17 ; \mathrm{N}, 12.68 ; \mathrm{S}, 9.68$; found: C, 58.05; H, 5.21; N, 12.49; S, 9.72 .

\section{2,3-Dihydro-1H-1,3-benzodiazol-2-one, 5}

In a two-neck flamed-dried flask, a solution of $o$-phenylenediamine $(30 \mathrm{mg}, 0.28 \mathrm{mmol})$ and carbonyldiimidazole $(48 \mathrm{mg}, 0.30 \mathrm{mmol}$ ) in dry THF was heated at reflux overnight under an Ar atmosphere. After completion, the reaction was cooled to room temperature, and the solvent was evaporated under vacuum. The residue was acidified to $\mathrm{pH} 2$ with $2 \mathrm{M} \mathrm{HCl}$, and the precipitate was filtered off. The filtrate was dried in vacuo, and a white solid was obtained. The crude residue was purified by flash column chromatography (DCM/MeOH 95:5) to obtain product 5. Yield: 78\%. TLC (DCM/MeOH 9:1): $\mathrm{R}_{\mathrm{f}}: 0.22 . \mathrm{Mp}: 305-308{ }^{\circ} \mathrm{C} .{ }^{1} \mathrm{H}-\mathrm{NMR}\left(300 \mathrm{MHz}, \mathrm{CD}_{3} \mathrm{OD}\right): \delta 7.06-7.04(\mathrm{~m}, 4 \mathrm{H}, \mathrm{ArH})$ ppm. ${ }^{13} \mathrm{C}-\mathrm{NMR}\left(75 \mathrm{MHz}, \mathrm{CDCl}_{3}\right): \delta 156.6,129.4,121.1,108.9 \mathrm{ppm}$. Anal. calcd (\%) for $\mathrm{C}_{7} \mathrm{H}_{6} \mathrm{~N}_{2} \mathrm{O}: \mathrm{C}$, 62.68; H, 4.51; N, 20.88; found: C, 62.72; H, 4.58; N, 20.87.

\subsection{Single Crystal X-ray Analysis}

Diffraction data for compound 1 were collected by means of a Bruker AXS CCD-based three-circle diffractometer (Bruker AXS, Karlsruhe, Germany), working at ambient temperature with graphite-monochromatized Mo-K $\alpha$ X-radiation $(\lambda=0.71073 \AA)$.

$X$-ray diffraction data in the $\theta$ range of $2-30^{\circ}$ were collected by acquiring 4 sets of 600 bidimensional CCD frames with the following operative conditions: omega rotation axis, scan width $0.3^{\circ}$, acquisition time $30 \mathrm{~s}$, sample-to-detector distance $50 \mathrm{~mm}$, phi angle fixed at four different values $\left(0^{\circ}, 90^{\circ}, 180^{\circ}\right.$, and $270^{\circ}$ ) for the four different sets.

Omega-rotation frames were processed with the SAINT software (Bruker) for data reduction (including intensity integration, background, Lorentz, and polarization corrections) and for determination of accurate unit-cell dimensions, obtained by the least-squares refinement of the positions of 6048 independent reflections with $\mathrm{I}>10 \sigma(\mathrm{I})$ in the $\theta$ range $2-25^{\circ}$. Absorption effects were empirically evaluated by the SADABS software [46], and absorption correction was applied to the data (0.847 and $0.973 \mathrm{~min}$ and max transmission factors, respectively).

The structures were solved by direct methods (SIR-2014) [47] and completed by iterative cycles of full-matrix least-squares refinement on $F^{2}$ and $\triangle F$ synthesis using the SHELXL-17 [48] program (WinGX suite) [49]. The positions of hydrogen atoms were introduced at calculated positions in their described geometries and allowed to ride on the attached carbon atom with fixed isotropic thermal parameters (1.2 Ueq of the parent carbon atom). 
These data can be obtained free of charge via www.ccdc.cam.ac.uk/conts/retrieving.html (or from the Cambridge Crystallographic Data Centre, 12, Union Road, Cambridge CB21EZ, UK; Fax: +44-1223-336-033; or deposit@ccdc.cam.ac.uk). CCDC Number 1,982,708 number contains the supplementary crystallographic data for this paper.

Crystal data for compound 1: $\mathrm{C}_{16} \mathrm{H}_{20} \mathrm{~N}_{8} \mathrm{O}_{2} \mathrm{~S}_{1}, M_{\mathrm{r}}=396.48 \mathrm{~g} / \mathrm{mol}$, Tetragonal, Space group I41/a, $a=14.1731$ (7) $\AA, b=14.1731$ (7) $\AA, c=18.0847$ (9) $\AA, V=3632.8$ (5) $\AA^{3}, Z=8, D_{\text {calc }}=1.397 \mathrm{Mg} / \mathrm{m}^{3}$, $R=0.049$ (2655 reflections), $w R 2=0.133, T=293(2) \mathrm{K}, \mathrm{GOF}=1.029$. The reflections were collected in the range $1.78^{\circ} \leq \theta \leq 29.98^{\circ}$ employing a $0.41 \times 0.13 \times 0.013 \mathrm{~mm}$ crystal.

\subsection{Biological Evaluation}

AlphaScreen is a bead-based non-radioactive assay system for the detection of biomolecular interactions in a microtiter plate format. The binding of biological partners brings donor and acceptor beads into close proximity and, as a result, a fluorescent signal between 520 and $620 \mathrm{~nm}$ was produced. The AlphaScreen-based assays [50,51] were performed in a final reaction volume of $25 \mu \mathrm{L}$ of the assay buffer containing $10 \mathrm{mM}$ HEPES-NaOH (pH 7.4), $50 \mathrm{mM} \mathrm{NaCl}, 1 \mathrm{mM}$ EDTA (pH 8.0), 0.1\% $\mathrm{NP}-40$, and $10 \mathrm{ng} / \mu \mathrm{L}$ bovine serum albumin (BSA) in a 96-well microtiter plate at $25^{\circ} \mathrm{C}$. The pTyr peptide probes used in this study were 5-carboxyfluorescein (FITC)-GPYLPQTV for STAT3 and (FITC)-GpYDKPHVL for STAT1. Plasmid construction and protein expression were performed as previously described [52]; the experimental method is briefly summarized as follows. Considering that the expression of the full-length protein is troublesome, a truncated form of STAT3 (136-705) was constructed and chromatographically purified (AKTA FPLC system; GE Healthcare Bio-Sciences, Piscataway, NJ, USA). The soluble STAT3 fraction was loaded on a HisTrap ${ }^{\mathrm{TM}}$ column (GE Healthcare Bio-Sciences) and eluted with an imidazole gradient (50 mM Tris- $\mathrm{HCl} \mathrm{pH} \mathrm{7.4,300} \mathrm{mM} \mathrm{NaCl,} 0.2 \mathrm{mM}$ EDTA, $0.1 \%(w / v)$ NP-40, $5 \mathrm{mM} \beta$-mercaptoethanol, 10\% (v/v) glycerol, and 10-300 mM imidazole). An SDS-PAGE stained with Coomassie Brilliant Blue (CBB) was performed to check the purity of the protein (see Figure S71). Subsequently, the protein was dialyzed (10 mM HEPES-NaOH pH 7.4, $50 \mathrm{mM}$ $\mathrm{NaCl}, 10 \mathrm{mM} \beta$-mercaptoethanol, $0.1 \mathrm{mM}$ EGTA, $0.02 \%(w / v) \mathrm{NP}-40,0.2 \mathrm{mM}$ phenylmethylsulphonyl fluoride (PMSF), and $10 \%(v / v)$ glycerol).

Firstly, $75 \mathrm{nM}$ of each SH2-containing protein were incubated with the test compound (at the following concentrations: 1, 3, 10, and $30 \mu \mathrm{M}$ ) for $15 \mathrm{~min}$. Each protein sample was then incubated for 90 min with $50 \mathrm{nM}$ of its corresponding FITC-pTyr peptide and simultaneously mixed with streptavidin-coated donor beads and anti-FITC acceptor beads before detection at $570 \mathrm{~nm}$ using EnVison Xcite (PerkinElmer, Waltham, MA, USA).

The same procedure was used to evaluate compound 1 activity versus STAT3 single-cysteineresidue mutants (Cys468A, Cys542A, Cys550A, Cys687A, and Cys712A). Briefly, $3 \mu \mathrm{L}$ of compound 1 in DMSO (at $0.3,1,3,10$ and $30 \mu \mathrm{M}$ concentration) were premixed with $1 \mu \mathrm{L}$ of L-Cys in PBS and $16 \mu \mathrm{L}$ of an AlphaScreen buffer. Then, the mixture was immediately $(<5 \mathrm{~min})$ mixed with the STAT3 mutant solution before adding the FITC-peptide.

\subsection{Analytical Studies}

\subsubsection{MS, UV, and LC Analyses}

\section{Sample Preparation}

A compound 1 stock solution $(1 \mathrm{mg} / \mathrm{mL})$ was prepared in $\mathrm{MeOH}$. The stock solution for GSH was prepared at the same concentration in deionized water.

An aqueous buffer $(10 \mathrm{mM})$ for experiments at $\mathrm{pH} 2$ was prepared with $10 \mathrm{mM} \mathrm{H}_{3} \mathrm{PO}_{4} / \mathrm{NaH}_{2} \mathrm{PO}_{4}$, whereas $10 \mathrm{mM} \mathrm{NaH} \mathrm{PO}_{4} / \mathrm{Na}_{2} \mathrm{HPO}_{4}$ and $10 \mathrm{mM} \mathrm{NaHCO} / \mathrm{Na}_{2} \mathrm{CO}_{3}$ were used for the physiological buffer ( $\mathrm{pH}$ 7.4) and the basic buffer ( $\mathrm{pH}$ 10), respectively. For experiments under non-oxidizing conditions, $5 \mathrm{mM} \mathrm{Na}_{2} \mathrm{~S}_{2} \mathrm{O}_{5}$ was directly added into the buffers. 
Reaction batches were prepared by spiking into the desired buffer aliquots of stock solutions of compound 1 and GSH down to 0.5 and $1 \mathrm{mM}$, respectively. All reactions were kept at $37^{\circ} \mathrm{C}$ under gentle stirring for up to $24 \mathrm{~h}$.

Before MS experiments, all samples were diluted 1:10 with an aqueous solution containing 30\% acetonitrile and $0.1 \%$ formic acid to improve ionization.

Before LC injection, samples were diluted 1:5 with $24 \mathrm{mM} \mathrm{HCl}$. No additional dilution/sample treatment was required for UV spectroscopy.

MS Method

MS analyses were performed on an LTQ-Orbitrap ${ }^{\mathrm{TM}}$ XL mass spectrometer (Thermo Fisher Scientific, Waltham, MA, USA) equipped with a Finnigan Ion Max 2 electro-spray source (ESI) endowed with a metal capillary that was $140 \mathrm{~mm}$ long and had a $160 \mu \mathrm{m}$ inner diameter.

Samples were taken with a Hamilton glass syringe. The solution was injected by a pre-installed infuser at a flow rate of $5 \mu \mathrm{L} / \mathrm{min}$. Nebulization was carried out in positive ion mode with a spray voltage of $4 \mathrm{kV}, 10$ units of sheath gas at a capillary temperature of $275^{\circ} \mathrm{C}$, and an offset tube lens of $74 \mathrm{~V}$. Orbitrap ${ }^{\mathrm{TM}}$ analyzer acquired mass spectra with a scan range from 200 to $1000 \mathrm{~m} / \mathrm{z}$, recording $5 \times 10^{5}$ ion per scan with a resolution of 100,000 (full-width at half-maximum at a $400 \mathrm{~m} / \mathrm{z}$ ).

\section{UV Method}

UV spectra were performed with a Shimadzu UV-1900 (Shimadzu, Kyoto, Japan) by using UV PROBE 2.7 software (Shimadzu). Analyses were done with $1.5 \mathrm{~mL}$ quartz cuvettes (Hellma, Müllheim, Germany), acquiring the spectra in a scan range from 200 to $600 \mathrm{~nm}$.

\section{LC Method}

LC analysis was carried out with an HPLC Surveyor LC system (Thermo Finnigan) equipped with a quaternary pump, diode array (PDA) detector, autosampler, online degasser, and thermostat. Chromatographic separation was carried out with a Phenomenex ${ }^{\circledR}$ Kinetex C18 reverse-phase column (Phenomenex, Torrance, CA, USA; $25 \mathrm{~mm} \times 2.10 \mathrm{~mm}, 2.6 \mu \mathrm{m}$ particle diameter with $100 \AA$ pores). An OPTI-SOLV ${ }^{\circledR}$ Mini Filter (0.5 mm; Sigma-Aldrich-Merck) was installed before the column to protect it from particulates. A gradient program reported in Table 4 was used at $200 \mu \mathrm{L} / \mathrm{min}$ flow rate; as a mobile phase, $1 \mathrm{mM} \mathrm{HCl}$ ( $\mathrm{pH}$ 3) and acetonitrile were employed. The PDA detector worked in scan mode, acquiring UV spectra in a range from 200 to $600 \mathrm{~nm}$.

Table 4. LC-UV gradient program.

\begin{tabular}{ccc}
\hline Time (min) & $\mathbf{1} \mathbf{~ m M ~ H C l , ~} \mathbf{p H ~ 3 ~ ( A ) ~}$ & ACN (B) \\
\hline 0.00 & 95 & 5 \\
1.00 & 95 & 5 \\
16.00 & 30 & 70 \\
16.50 & 30 & 70 \\
16.51 & 95 & 5 \\
22.00 & 95 & 5 \\
\hline
\end{tabular}

\subsection{2. ${ }^{1} \mathrm{H}-\mathrm{NMR}$ Analysis}

${ }^{1} \mathrm{H}-\mathrm{NMR}$ analysis was performed at $500 \mathrm{MHz}$ with a Bruker FT-NMR AVANCETM DRX500 spectrometer (Bruker, Billerica, MA, USA) using a $5 \mathrm{~mm}$ z-PFG (pulsed field gradient) broadband reverse probe at $298 \mathrm{~K}$. The experimental procedure was designed as follows: a $10 \mathrm{mM} \mathrm{pH} 10$ carbonate buffer solution in $\mathrm{D}_{2} \mathrm{O}$ was used as the solvent for $\mathrm{NMR}$ analysis. $\mathrm{Na}_{2} \mathrm{~S}_{2} \mathrm{O}_{5}(20 \mathrm{mg}, 0.1 \mathrm{mmol})$ was dissolved in $1 \mathrm{~mL}$ of the solvent, and (1) compound 1 (5 mg, $0.025 \mathrm{mmol})$, (2) GSH (16 mg, $0.05 \mathrm{mmol}$ ), or (3) compound 1 ( $5 \mathrm{mg}, 0.025 \mathrm{mmol})$ and GSH (16 mg, $0.05 \mathrm{mmol})$ were dissolved in $0.7 \mathrm{~mL}$ of such a solution. Notably, when $\mathrm{Na}_{2} \mathrm{~S}_{2} \mathrm{O}_{5}$ was added, the $\mathrm{pH}$ of the solution was slightly lowered below the 
value of $10(\mathrm{pH} \leq 10)$. Each sample was immediately put into the NMR tube and analyzed (time 0$)$ at $298 \mathrm{~K}$. Then, they were heated at $37^{\circ} \mathrm{C}$ in a thermostatic bath, and their ${ }^{1} \mathrm{H}-\mathrm{NMR}$ spectra were collected after different times at $298 \mathrm{~K}$.

\section{Conclusions}

Benzothiadiazole derivative $\mathbf{1}$ was identified as a novel STAT3 inhibitor by structure-based virtual screening performed on the SH2 domain. The AlphaScreen-based assay confirmed, albeit indirectly, that compound 1 was able to inhibit STAT3 dimerization, exhibiting a good activity $\left(\mathrm{STAT}_{3} \mathrm{IC}_{50}=\right.$ $15.8 \pm 0.6 \mu \mathrm{M}$ versus STAT1 $\left.\mathrm{IC}_{50}>50 \mu \mathrm{M}\right)$. Therefore, a small set of derivatives was designed and synthesized through a flexible diversity-oriented synthetic approach when required. The compounds were tested to define the main structural features for the lead development. Among them, only compound 1d exhibited a significant, albeit reduced, activity, thus suggesting a considerably "tight" SAR for this class of derivatives. Moreover, because compound 1, like other known STAT3 inhibitors, probably binds to cysteine residues, MS, UV, LC, and NMR studies were performed to understand its mechanism of interaction. Mimicking the biological conditions, we conducted an MS analysis of compound 1 in the presence of GSH: We discovered that this inhibitor can covalently bind to cysteine residues through a Michael-like reaction, leading to the formation of some alkylation adducts.

In an attempt to confirm the results of the MS study, an NMR investigation was carried out to further characterize the adducts formed by the interaction of compound $\mathbf{1}$ with GSH. However, despite the same reaction conditions $(\mathrm{pH}$, temperature, and use of an antioxidant) being employed, the intrinsic differences between the two techniques prevented us from obtaining additional evidence to support the MS conclusions. Notably, NMR spectroscopy is seldom used for this kind of study in the literature $[16,18]$, which suggests that its inherent limitations make it unsuitable for such an application. Therefore, it would seem reasonable to claim that the NMR results neither supported nor disproved our hypotheses.

The research of STAT3 inhibitors has led to several potent anti-tumor candidates over the years (e.g., Stattic, S3I-201, and erasin). In this context, we are confident that our ongoing studies will allow us to develop and improve our lead compound $\mathbf{1}$ as a new PPI inhibitor endowed with a novel mechanism of interaction and characterized by a $\mathrm{pH}$-dependent activation.

Supplementary Materials: The following are available online: Tables S1-S5: Top-ranked compounds from computational studies; Figure S1: Main SH2 domain residues involved in the interaction with compound 1; Table S6: Pan-assay interference compound (PAINS) in silico prediction test, employing five on-line services (SmartsFilter, SwissADME, Zinc Patterns, FAF-Drugs4, and PAINS remover); Figures S2-S70: ${ }^{1} \mathrm{H}$ and ${ }^{13} \mathrm{C}-\mathrm{NMR}$ spectra of synthesized compounds; Table S7: Effect of cysteine on the inhibitory activity of compound 1 versus STAT3; Table S8: Effect of the mutation of cysteine residues located in the vicinities of the SH2 domain on the inhibitory activity of compound 1 versus STAT3; Figure S71: CBB staining of the STAT3(136-705) and STAT5b(136-703) proteins. The purified soluble proteins $(0.5 \mu \mathrm{g})$ were analyzed by SDS-PAGE; Table S9: Comparison of the best STAT3 complexes obtained by docking compound 1 into the pockets containing the mutated cysteines, considered in the mutagenesis study; Figure S72: Main interactions of compound 1 into the pocket lined by Cys712; Page S52: NMR studies; Figure S73-S75: ${ }^{1} \mathrm{H}-\mathrm{NMR}$ full spectra and expansions related to the NMR analysis of compound 1/GSH.

Author Contributions: Conceptualization, A.G. and S.V.; computational studies, A.P.; synthesis and characterization, M.M., A.G., and S.V.; crystallographic studies, F.M., M.M., and G.P.; biological evaluation, A.A.; M.S., U.V., and L.C. analyses, L.R. and E.G.; ${ }^{1}$ H-NMR analysis, D.C.; writing—original draft preparation, A.G. and S.V.; writing-review and editing, A.G., S.V., and M.M.; supervision, A.G., S.V., and M.M. All authors have read and agreed to the published version of the manuscript.

Funding: This research received no external funding.

Acknowledgments: The authors gratefully thank Rachele Iannarone, Carlo Baschieri, Luca Oliva, Daniela Masciocchi and Daniela Barlocco for their helpful support.

Conflicts of Interest: The authors declare no conflict of interest. 


\section{References}

1. Masciocchi, D.; Gelain, A.; Villa, S.; Meneghetti, F.; Barlocco, D. Signal transducer and activator of transcription 3 (STAT3): A promising target for anticancer therapy. Future Med. Chem. 2011, 3, 567-597. [CrossRef] [PubMed]

2. Gelain, A.; Mori, M.; Meneghetti, F.; Villa, S. Signal Transducer and Activator of Transcription Protein 3 (STAT3): An Update on its Direct Inhibitors as Promising Anticancer Agents. Curr. Med. Chem. 2018, 26, 5165-5206. [CrossRef]

3. Furtek, S.L.; Backos, D.S.; Matheson, C.J.; Reigan, P. Strategies and Approaches of Targeting STAT3 for Cancer Treatment. ACS Chem. Biol. 2016, 11, 308-318. [CrossRef] [PubMed]

4. $\quad$ Lis, C.; Rubner, S.; Roatsch, M.; Berg, A.; Gilcrest, T.; Fu, D.; Nguyen, E.; Schmidt, A.M.; Krautscheid, H.; Meiler, J.; et al. Development of Erasin: A chromone-based STAT3 inhibitor which induces apoptosis in Erlotinib-resistant lung cancer cells. Sci. Rep. 2017, 7, 1-10. [CrossRef] [PubMed]

5. Oh, D.Y.; Lee, S.H.; Han, S.W.; Kim, M.J.; Kim, T.M.; Kim, T.Y.; Heo, D.S.; Yuasa, M.; Yanagihara, Y.; Bang, Y.J. Phase I study of OPB-31121, an oral STAT3 inhibitor, in patients with advanced solid tumors. Cancer Res. Treat. 2015, 47, 607-615. [CrossRef]

6. Keskin, O.; Gursoy, A.; Ma, B.; Nussinov, R. Principles of protein-protein interactions: What are the preferred ways for proteins to interact? Chem. Rev. 2008, 108, 1225-1244. [CrossRef]

7. Wells, J.A.; McClendon, C.L. Reaching for high-hanging fruit in drug discovery at protein-protein interfaces. Nature 2007, 450, 1001-1009. [CrossRef]

8. Shin, D.S.; Masciocchi, D.; Gelain, A.; Villa, S.; Barlocco, D.; Meneghetti, F.; Pedretti, A.; Han, Y.M.; Han, D.C.; Kwon, B.M.; et al. Synthesis, modeling, and crystallographic study of 3,4-disubstituted-1,2,5-oxadiazoles and evaluation of their ability to decrease STAT3 activity. Medchemcomm 2010, 1, 156-164. [CrossRef]

9. Masciocchi, D.; Villa, S.; Meneghetti, F.; Pedretti, A.; Barlocco, D.; Legnani, L.; Toma, L.; Kwon, B.M.; Nakano, S.; Asai, A.; et al. Biological and computational evaluation of an oxadiazole derivative (MD77) as a new lead for direct STAT3 inhibitors. Medchemcomm 2012, 3, 592-599. [CrossRef]

10. Masciocchi, D.; Gelain, A.; Porta, F.; Meneghetti, F.; Pedretti, A.; Celentano, G.; Barlocco, D.; Legnani, L.; Toma, L.; Kwon, B.M.; et al. Synthesis, structure-activity relationships and stereochemical investigations of new tricyclic pyridazinone derivatives as potential STAT3 inhibitors. Medchemcomm 2013, 4, 1181-1188. [CrossRef]

11. Meneghetti, F.; Villa, S.; Masciocchi, D.; Barlocco, D.; Toma, L.; Han, D.C.; Kwon, B.M.; Ogo, N.; Asai, A.; Legnani, L.; et al. Ureido-Pyridazinone Derivatives: Insights into the Structural and Conformational Properties for STAT3 Inhibition. Eur. J. Org. Chem. 2015, 2015, 4907-4912. [CrossRef]

12. Gabriele, E.; Porta, F.; Facchetti, G.; Galli, C.; Gelain, A.; Meneghetti, F.; Rimoldi, I.; Romeo, S.; Villa, S.; Ricci, C.; et al. Synthesis of new dithiolethione and methanethiosulfonate systems endowed with pharmaceutical interest. Arkivoc 2016, 2017, 235-250. [CrossRef]

13. Porta, F.; Facchetti, G.; Ferri, N.; Gelain, A.; Meneghetti, F.; Villa, S.; Barlocco, D.; Masciocchi, D.; Asai, A.; Miyoshi, N.; et al. An in vivo active 1,2,5-oxadiazole Pt(II) complex: A promising anticancer agent endowed with STAT3 inhibitory properties. Eur. J. Med. Chem. 2017, 131, 196-206. [CrossRef] [PubMed]

14. Colyer, D.E.; Nortcliffe, A.; Wheeler, S. A general synthetic strategy for 1,3-dihydro-2,1,3-benzothiadiazole 2,2-dioxides (benzosulfamides). Tetrahedron Lett. 2010, 51, 5306-5308. [CrossRef]

15. Buettner, R.; Corzano, R.; Rashid, R.; Lin, J.; Senthil, M.; Hedvat, M.; Schroeder, A.; Mao, A.; Herrmann, A.; Yim, J.; et al. Alkylation of cysteine 468 in stat 3 defines a novel site for therapeutic development. ACS Chem. Biol. 2011, 6, 432-443. [CrossRef]

16. Heidelberger, S.; Zinzalla, G.; Antonow, D.; Essex, S.; Piku Basu, B.; Palmer, J.; Husby, J.; Jackson, P.J.M.; Rahman, K.M.; Wilderspin, A.F.; et al. Investigation of the protein alkylation sites of the STAT3:STAT3 inhibitor Stattic by mass spectrometry. Bioorg. Med. Chem. Lett. 2013, 23, 4719-4722. [CrossRef]

17. Fletcher, S.; Page, B.D.G.; Zhang, X.; Yue, P.; Li, Z.H.; Sharmeen, S.; Singh, J.; Zhao, W.; Schimmer, A.D.; Trudel, S.; et al. Antagonism of the Stat3-Stat3 Protein Dimer with Salicylic Acid Based Small Molecules. Chem. Med. Chem. 2011, 6, 1459-1470. [CrossRef]

18. Ball, D.P.; Lewis, A.M.; Williams, D.; Resetca, D.; Wilson, D.J.; Gunning, P.T. Signal transducer and activator of transcription 3 (STAT3) inhibitor, S3I-201, acts as a potent and non-selective alkylating agent. Oncotarget 2016, 7, 20669-20679. [CrossRef] 
19. Becker, S.; Groner, B.; Müller, C.W. Three-dimensional structure of the Stat $3 \beta$ homodimer bound to DNA. Nature 1998, 394, 145-151. [CrossRef]

20. Goodsell, D.S.; Olson, A.J. Automated docking of substrates to proteins by simulated annealing. Proteins Struct. Funct. Bioinform. 1990, 8, 195-202. [CrossRef]

21. Schmidhammer, H.; Hohenlohe-Oehringen, K. Synthesis of dopa and dopamine analogs with acidic imido-functionalities in heterocyclic ring moieties instead of the phenolic hydroxyl groups. Sci. Pharm. 1983, 51, 8-16.

22. Burke, P.O.; McDermott, S.D.; Hannigan, T.J.; Spillane, W.J. Basicity of nitrogen-sulphur(VI) compounds. Part 6. Ionization of $\mathrm{NN}^{\prime}$-di-and $\mathrm{N}$-mono-substituted sulphamides and dihydro-2,1,3-benzothiadiazoline and benzothiadiazine 2,2-dioxides (cyclic sulphamides). J. Chem. Soc. Perkin Trans. 1984, 2, 1851-1854. [CrossRef]

23. Farrugia, L.J. WinGX suite for small-molecule single-crystal crystallography. J. Appl. Crystallogr. 1999, 32, 837-838. [CrossRef]

24. Kortylewski, M.; Jove, R.; Yu, H. Targeting STAT3 affects melanoma on multiple fronts. Cancer Metastasis Rev. 2005, 24, 315-327. [CrossRef]

25. McMurray, J.S.; Klostergaard, J. STAT3 Signaling in Cancer: Small Molecule Intervention as Therapy? In Anti-Angiogenesis Drug Discovery and Development; Elsevier: Amsterdam, The Netherlands, 2014; pp. $216-267$.

26. Dahlin, J.L.; Nissink, J.W.M.; Strasser, J.M.; Francis, S.; Higgins, L.; Zhou, H.; Zhang, Z.; Walters, M.A. PAINS in the assay: Chemical mechanisms of assay interference and promiscuous enzymatic inhibition observed during a sulfhydryl-scavenging HTS. J. Med. Chem. 2015, 58, 2091-2113. [CrossRef] [PubMed]

27. FAF-Drugs3: A Web Server for Compound Property Calculation and Chemical Library Design-PubMed. Available online: https://pubmed.ncbi.nlm.nih.gov/25883137/ (accessed on 13 July 2020).

28. Baell, J.B.; Holloway, G.A. New substructure filters for removal of pan assay interference compounds (PAINS) from screening libraries and for their exclusion in bioassays. J. Med. Chem. 2010, 53, 2719-2740. [CrossRef]

29. Daina, A.; Michielin, O.; Zoete, V. SwissADME: A free web tool to evaluate pharmacokinetics, drug-likeness and medicinal chemistry friendliness of small molecules. Sci. Rep. 2017, 7, 1-13. [CrossRef]

30. Madeira, F.; Park, Y.M.; Lee, J.; Buso, N.; Gur, T.; Madhusoodanan, N.; Basutkar, P.; Tivey, A.R.N.; Potter, S.C.; Finn, R.D.; et al. The EMBL-EBI search and sequence analysis tools APIs in 2019. Nucleic Acids Res. 2019, 47, W636-W641. [CrossRef] [PubMed]

31. Wen, B.; Fitch, W.L. Screening and characterization of reactive metabolites using glutathione ethyl ester in combination with Q-trap mass spectrometry. J. Mass Spectrom. 2009, 44, 90-100. [CrossRef]

32. Mayer, R.J.; Ofial, A.R. Nucleophilicity of Glutathione: A Link to Michael Acceptor Reactivities. Angezw. Chem.-Int. Ed. 2019, 58, 17704-17708. [CrossRef]

33. Maier, G.P.; Bernt, C.M.; Butler, A. Catechol oxidation: Considerations in the design of wet adhesive materials. Biomater. Sci. 2018, 6, 332-339. [CrossRef] [PubMed]

34. Asiamah, I.; Krol, E.S. Quadrupole linear ion-trap mass spectrometry studies on glutathione conjugates of nordihydroguaiaretic acid (NDGA) analogues reveals phenol-type analogues are without reactive metabolite-mediated toxic liability. Cogent Chem. 2018, 4, 1562858. [CrossRef]

35. Iverson, S.L.; Shen, L.; Anlar, N.; Bolton, J.L. Bioactivation of estrone and its catechol metabolites to quinoid-glutathione conjugates in rat liver microsomes. Chem. Res. Toxicol. 1996, 9, 492-499. [CrossRef] [PubMed]

36. Toteva, M.M.; Richard, J.P. The generation and reactions of quinone methides. Adv. Phys. Org. Chem. 2011, 45, 39-91. [CrossRef] [PubMed]

37. Ali, A.M.; Gómez-Biagi, R.F.; Rosa, D.A.; Lai, P.-S.; Heaton, W.L.; Park, J.S.; Eiring, A.M.; Vellore, N.A.; de Araujo, E.D.; Ball, D.P.; et al. Disarming an Electrophilic Warhead: Retaining Potency in Tyrosine Kinase Inhibitor (TKI)-Resistant CML Lines While Circumventing Pharmacokinetic Liabilities. ChemMedChem 2016, 11, 850-861. [CrossRef]

38. Vila-Viçosa, D.; Teixeira, V.H.; Santos, H.A.F.; Machuqueiro, M. Conformational study of GSH and GSSG using constant-pH molecular dynamics simulations. J. Phys. Chem. B 2013, 117, 7507-7517. [CrossRef]

39. Pedretti, A.; Villa, L.; Vistoli, G. VEGA: A versatile program to convert, handle and visualize molecular structure on Windows-based PCs. J. Mol. Graph. Model. 2002, 21, 47-49. [CrossRef]

40. Gasteiger, J.; Marsili, M. Iterative partial equalization of orbital electronegativity-a rapid access to atomic charges. Tetrahedron 1980, 36, 3219-3228. [CrossRef] 
41. MacKerell, A.D.; Bashford, D.; Bellott, M.; Dunbrack, R.L.; Evanseck, J.D.; Field, M.J.; Fischer, S.; Gao, J.; Guo, H.; Ha, S.; et al. All-atom empirical potential for molecular modeling and dynamics studies of proteins. J. Phys. Chem. B 1998, 102, 3586-3616. [CrossRef]

42. Foloppe, N.; Alexander, D.; MacKerell, J. All-atom empirical force field for nucleic acids: I. Parameter optimization based on small molecule and condensed phase macromolecular target data. J. Comput. Chem. 2000, 21, 86-104. [CrossRef]

43. Phillips, J.C.; Braun, R.; Wang, W.; Gumbart, J.; Tajkhorshid, E.; Villa, E.; Chipot, C.; Skeel, R.D.; Kalé, L.; Schulten, K. Scalable molecular dynamics with NAMD. J. Comput. Chem. 2008, 26, 1781-1802. [CrossRef]

44. Grotthuss, M.; Koczyk, G.; Pas, J.; Wyrwicz, L.; Rychlewski, L. Ligand.Info Small-Molecule Meta-Database. Comb. Chem. High Throughput Screen. 2005, 7, 757-761. [CrossRef] [PubMed]

45. Pedretti, A.; Mazzolari, A.; Vistoli, G. WarpEngine, a Flexible Platform for Distributed Computing Implemented in the VEGA Program and Specially Targeted for Virtual Screening Studies. J. Chem. Inf. Model. 2018, 58, 1154-1160. [CrossRef]

46. Krause, L.; Herbst-Irmer, R.; Sheldrick, G.M.; Stalke, D. Comparison of silver and molybdenum microfocus X-ray sources for single-crystal structure determination. J. Appl. Crystallogr. 2015, 48, 3-10. [CrossRef] [PubMed]

47. Burla, M.C.; Caliandro, R.; Carrozzini, B.; Cascarano, G.L.; Cuocci, C.; Giacovazzo, C.; Mallamo, M.; Mazzone, A.; Polidori, G. Crystal structure determination and refinement via SIR2014. J. Appl. Crystallogr. 2015, 48, 306-309. [CrossRef]

48. Sheldrick, G.M. Crystal structure refinement with SHELXL. Acta Crystallogr. Sect. C Struct. Chem. 2015, 71, 3-8. [CrossRef]

49. Farrugia, L.J. WinGX and ORTEP for Windows: An update. J. Appl. Crystallogr. 2012, 45, 849-854. [CrossRef]

50. Matsuno, K.; Masuda, Y.; Uehara, Y.; Sato, H.; Muroya, A.; Takahashi, O.; Yokotagawa, T.; Furuya, T.; Okawara, T.; Otsuka, M.; et al. Identification of a new series of STAT3 inhibitors by virtual screening. ACS Med. Chem. Lett. 2010, 1, 371-375. [CrossRef]

51. Uehara, Y.; Mochizuki, M.; Matsuno, K.; Haino, T.; Asai, A. Novel high-throughput screening system for identifying STAT3-SH2 antagonists. Biochem. Biophys. Res. Commun. 2009, 380, 627-631. [CrossRef]

52. Asai, A.; Takakuma, K. Expression and Purification of Soluble STAT5b/STAT3 Proteins for SH2 Domain Binding Assay. In SH2 Domains: Methods and Protocols; Machida, K., Liu, B.A., Eds.; Springer: New York, NY, USA, 2017; pp. 163-172.

Sample Availability: Samples of the tested compounds (1a-i, 2a-b, $\mathbf{4}-\mathbf{6})$ are available upon request from the authors.

(C) 2020 by the authors. Licensee MDPI, Basel, Switzerland. This article is an open access article distributed under the terms and conditions of the Creative Commons Attribution (CC BY) license (http://creativecommons.org/licenses/by/4.0/). 